\section{PAKKOAVIOLIITON KRIMINALISOINTI SUOMESSA}

\section{THE CRIMINALISATION OF FORCED MARRIAGE IN FINLAND}

Nanni Olsson'

Helsinki Law Review, 1/2019, pp. 92-121

@ 2019 Pykälä ry, Mannerheimintie 3 B, 5th floor, 00100 Helsinki, Finland, and the author.

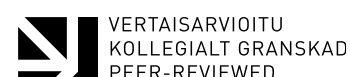

KOLLEGIALT GRANSKA
PEER-REVIEWED
www.tsv.filtunnus

Asiasanat:

pakkoavioliitto, Istanbulin sopimus, kriminalisointi, rikosoikeus, inmisoikeudet

Keywords:

forced marriage, the Istanbul Convention, criminalisation, criminal law, human rights

\section{ABSTRACT}

Every year, dozens of forced marriages are discovered in Finland. However, none of these have been prosecuted. In 2015, Finland ratified the Council of Europe Convention on Preventing and Combating Violence against Women and Domestic Violence, known as the 'Istanbul Convention', which explicitly requires States to criminalise intentional conduct forcing an adult or a child to enter into a marriage. This article evaluates the legislative measures made by the Finnish legislator in order to implement the Istanbul Convention, the potential need to criminalise forced marriage as a specific offence and the need for the crime to be subject to public prosecution. At the time of writing, forcing a person to enter into a marriage can be prosecuted as trafficking in human beings or as coercion. This article aims to show that these measures are insufficient. The findings indicate that criminalisation of forced marriage as a specific offence would be justified taking into account the principle of legality as well as Finland's treaty obligations and duties to protect and to fulfil human rights.

\section{JOHDANTO}

"[Suomessa asuva maahanmuuttajamies] lähti etsimään kotimaasta vaimoa. Hän löysi kauniin tytön ja päätti, että hänen kanssaan hän menee naimisiin. Ja hänen vanhemmat menevät tytön vanhempien luokse ja keskustelivat. Tyttö eikä hänen vanhempansa halunneet, että tyttö menisi naimisiin. Mutta mies kuitenkin halusi sitä. Hän löysi sen hetken, että raiskasi sen tytön ja sen kautta hän pääsi naimisiin. [...] Hänet [tyttö] oli raiskattu, jottei hänellä olisi vaihtoehtoa. Ne suvut sopivat siellä, että kyllä lähtevät tänne Suomeen ja tyttö menee opiskelemaan ja kaikki järjestyy hyvin. Mutta kun tyttö tuli tänne, hän oli jo raskaana, hän ei päässyt mihinkään opiskelemaan ja mies piti häntä kurissa. Jos kysyt, mikä tässä on kunniaa. Kunniaa tässä on raiskaus. Silloin ei ole vaihtoehtoa, kun kunnia on menetetty, että se oli käyttänyt sitä keinoa."2

Yllä oleva haastattelu on osa Ihmisoikeusliiton selvitystä kunniaan liittyvästä väkivallasta ja siihen puuttumisesta Suomessa. Kansainvälinen työjärjestö ILO on modernia orjuutta koskevassa raportissaan arvioinut 15,4 miljoonan ihmisen eläneen pakkoavioliitossa maailmanlaajuisesti vuonna 2016. Heistä noin 340000 ihmisen arvioidaan eläneen pakkoavioliitossa Euroopassa ja Keski-Aasiassa. ${ }^{3}$ Maahanmuuton lisääntyessä Suomi on uudenlaisten haasteiden edessä ihmisoikeuksien toteuttamiseksi. Väestöliiton julkaisussa maahanmuuttajanaisten kotoutumisesta havaitaan tyttöjen ja naisten seksuaalisuuden ja maineen tulevan Suomessa vielä tiukemman kontrollin alaisiksi kuin entisessä kotimaassa. ${ }^{4}$ Näin ollen pakkoavioliitot ovat Suomessakin uhka, johon yhteiskunnan tulee vastata.

Artikkelissani tarkastelen avioliittoon pakottamisen kriminalisointia Suomessa suhteessa velvoitteisiin, joita Euroopan neuvoston yleissopimus naisiin kohdistuvan väkivallan ja perheväkivallan ehkäisemisestä ja torjumisesta (Sops 53/2015, jäljempänä Istanbulin sopimus) sopimusosapuolille asettaa. Tavoitteena on punnita Suomen lainsäädännöllisiä valintoja rikosoikeuden kentällä Istanbulin sopimusta ratifioitaessa, mahdollisen erilliskriminalisoinnin tarkoituksenmukaisuutta sekä virallisen syytteen alaisuutta.

Pakkoavioliitto on luokiteltu naisiin kohdistuvan väkivallan muodoksi, joka tuomitaan useissa kansainvälisissä instrumenteissa. ${ }^{\mathbf{5}}$ Muiden instrumenttien tarkastelu Istanbulin sopimuksen rinnalla ei kuitenkaan toisi kriminalisointivelvoitteen käsittelylle juurikaan lisäarvoa. Istanbulin sopimusta voidaan pitää ihmisoikeusnäkökulmasta kattavana - siinä on otettu huomioon niin

2 Hansen ym. 2016, s. 87.

Global estimates of modern slavery: forced labour and forced marriage 2017, s. 43-44.

Martikainen \& Tiilikainen 2007, s. 28.

5 Ks. esim. CEDAW General Recommendation No. 19: Violence against women. UN Committee on the Elimination of Discrimination Against Women, 1992, Declaration on the Elimination of Violence against Women. United Nations General Assembly, 20.12.1993, Pekingin julistus ja toimintaohjelma. Neljäs naisten asemaa käsittelevä maailmankonferenssi 15.9.1995. 
relevantit Euroopan ihmisoikeustuomioistuimen ratkaisut kuin CEDAW-sopimuksen (SopS 67/1986) noudattamista valvovan komitean keskeiset suositukset ja käytännötkin. ${ }^{6}$ Näin ollen tarkastelu keskittyy Istanbulin sopimukseen, joka selkeimmin vaatii jäsenmailta pakkoavioliiton säätämistä rangaistavaksi.

Työssä on ollut tarpeen tehdä useita rajauksia. Erityisesti lapsiavioliitot nivoutuvat vahvasti pakkoavioliittoihin, sillä kansainvälisten tutkimusten mukaan jopa kolmannes länsimaissa esiin tulevista pakkoavioliitoista on lapsiavioliitto. ${ }^{7}$ Lapsiavioliittoihin sisältyy kuitenkin myös erityispiirteitä, joita ei tässä työssä voida käsitellä. Rajauksesta huolimatta on tärkeää pitää mielessä, että uhrin heikompaan asemaan vaikuttaa usein myös tämän ikä. Artikkeli perehtyy maahanmuuttajaväestöä koskeviin pakkoavioliittoihin, sillä niistä on tarjolla tutkimustietoa. ${ }^{\mathbf{8}}$ Lisäksi tarkastelu rajataan Suomeen, vaikka pakkoavioliitto on täällä korostetusti kulttuuri- ja valtiorajat ylittävä ilmiö. Oikeusvertaileviin näkökohtiin ei ole tässä työssä mahdollista kuitenkaan paneutua. Mainitsemisen arvoista kuitenkin on, että useissa länsimaissa, Ruotsi mukaan lukien, pakkoavioliitto on nimenomaisesti kriminalisoitu. ${ }^{9}$

Artikkelin lähdeaineistona on käytetty lainvalmisteluaineiston ja oikeuskirjallisuuden ohella etenkin viimeaikaisia Ihmisoikeusliiton sekä Kriminologian ja oikeuspolitiikan instituutin tekemiä selvityksiä pakkoavioliitoista Suomessa. Ne ovat osoittautuneet arvokkaiksi lähteiksi konkreettisessa tarkastelussa, sillä ilmiötä on tutkittu Suomessa toistaiseksi varsin vähän. Pakkoavioliitot eivät juuri näy suomalaisessa oikeuskäytännössä, joten asian parissa työskentelevien järjestöjen havainnot ilmiöstä saavat painoarvoa.

Aiheen tarkastelu aloitetaan keskeisten käsitteiden määrittelyllä, minkä jälkeen siirrytään tarkastelemaan pakkoavioliittojen esiintymistä Suomessa sekä vaarassa olevia oikeushyviä. Sitä säätelevistä kansainvälisistä instrumenteista perehdytään tarkemmin Istanbulin sopimuksen osapuolille asettamiin velvoitteisiin. Näiden sopimusvelvoitteiden esittelyn jälkeen arvioidaan kansallisen lainsäätäjän valintoja niiden täyttämiseksi. Artikkelissa tuodaan esiin sekä ihmiskauppasääntelyyn että pakottamisen soveltumiseen liittyvä ongelmallisuus, minkä seurauksena arvioidaan mahdollisen erilliskriminalisoinnin hyötyjä ja haittoja. Ongelmat ovat monisyisiä, joten tarkastelu kohdistuu niin periaatteelliselle kuin käytännön tasolle. Johtopäätöksissä pyritään kiteyttämään arvioinnin tulokset ja siten ottamaan kantaa pakkoavioliiton kriminalisointiin Suomessa de lege ferenda.

Oksanen 2012, s. 619. CEDAW-sopimus on YK:n kaikkinaisen naisten syrjinnän poistamista koskeva yleissopimus.

7 Ks. esim. Forced Marriage Unit Statistics 2016, s. 7.

Ks. esim. Hansen ym. 2016 s. 83-87. Huomionarvoista on kuitenkin, ettei pakkoavioliitoista ole tilastoja. Ongelmalliseksi ilmiön tekee myös se, että vain osa tapauksista tulee julki. Näin ollen ei ole poissuljettua, ettei pakkoavioliittoja esiintyisi myös kantaväestön tai muiden vähemmistöryhmien keskuudessa.

9 Brottsbalk (1962:700) 4 kap. 4 с .

\section{TARKASTELUN LÄHTÖKOHTIA}

\section{I Keskeisiä käsitteitä}

Pakkoavioliitto. Pakkoavioliitolle ei ole olemassa yhtä, yleisesti hyväksyttyä määritelmää. Tässä artikkelissa noudatetaan Euroopan neuvoston määritelmää johtuen artikkelin kytkeytymisestä Istanbulin sopimukseen. Näin ollen pakkoavioliitolla tarkoitetaan liittoa, johon vähintään toinen osapuolista ei ole antanut vapaata ja täyttä suostumustaan. ${ }^{10}$ Liitolla voidaan viitata myös esimerkiksi sellaiseen uskonnolliseen avioliittoon, jota ei ole laadittu Suomen lainsäädännön mukaisesti ja jota ei siten tunnusteta täällä virallisesti avioliitoksi.

Järjestetty avioliitto. Pakkoavioliiton ja järjestetyn avioliiton välinen raja voi olla vaikea hahmottaa ja vielä vaikeampi näyttää toteen. Avioliitto on molemmissa tapauksissa ulkopuolisen järjestämä, mutta puolisoiden vapaaehtoinen suostumus tai sen puute erottaa ne toisistaan." Markku Helin käsittelee tätä rajanvetoa nostaen esiin sen, että myös järjestetyissä avioliitoissa voi puolisoiden suostumuksen taustalla olla omia valintoja vahvemmin sosiaalinen paine. Huomionarvoista on, ettei omassa lainsäädännössämmekään ole määritelty sitä, mihin motiiveihin avioitumisen tulee perustua. ${ }^{\mathbf{1 2}}$ Artikkelin tarkoitus ei ole arvottaa länsimaisia "rakkausavioliittoja" suhteessa järjestettyihin avioliittoihin, vaan keskittyä näistä erillisiin pakkoavioliittoihin.

Istanbulin sopimus. Euroopan neuvoston yleissopimus naisiin kohdistuvan väkivallan ja perheväkivallan ehkäisemisestä ja torjumisesta tunnetaan Istanbulin sopimuksena, ja se on Euroopassa ensimmäinen oikeudellisesti sitova sopimus naisten suojelemiseksi väkivallalta. ${ }^{13}$ Sopimus suojelee myös miehiä ja poikia perheväkivallalta. Sopimuksen mukaan rangaistavaa on muun muassa aikuisen tai lapsen pakottaminen avioliittoon.

Kriminalisointi. Kriminalisoinnilla tarkoitetaan lainsäätäjän päätöstä liittää tiettyyn käyttäytymiseen rangaistusuhka, eli teon säätämistä rikoslaissa (39/1889) rangaistavaksi. ${ }^{14}$ Tässä artikkelissa painopiste on pakkoavioliiton erilliskriminalisoinnissa, eli sen nimenomaisessa säätämisessä rangaistavaksi. Tällöin teko olisi rikoslaissa yksilöity, eikä siitä rankaiseminen riippuisi muiden rikosnimikkeiden soveltumisesta. Tässä artikkelissa kiinnostuksen kohteena on myös se, onko rikos virallisen syytteen alainen vaiko asianomistajarikos.

\subsection{Pakkoavioliittojen esiintyminen Suomessa}

Nojautuen Virve Toivosen oikeusministeriön pyynnöstä laatimaan selvitykseen Pakkoavioliittojen esiintyminen ja ilmitulo Suomessa voidaan Suomessa katsoa esiintyvän kolmen tyyppisiä

10 Parliamentary Assembly Resolution 14685.10 .2005

11 Rude-Antoine 2005, s. 17-18.

12 Helin 2013, s. 178

13 Ulkoministeriö 17.4.2015.

14 Ks. esim. Frände 2005, s. 21 
pakkoavioliittotapauksia. Ensimmäisessä tyypissä on kyse ulkomailla solmitusta, ulkomaalaisten välisestä liitosta, joka voi tulla Suomessa esiin esimerkiksi Maahanmuuttoviraston turvapaikkaselvityksissä. Toisessa tyypissä Suomessa asuva maahanmuuttajataustainen tyttö tai nuori nainen pakotetaan avioliittoon ulkomailla asuvan miehen kanssa. Pariskunnan ikäero voi olla suurikin, ja syynä liittoon voivat olla niin oleskeluluvan saaminen kuin kulttuuriset tekijät. Nämä liitot vaikuttavat edellä mainittuun selvitykseen koottujen haastattelujen perusteella yleisimmiltä. Kolmas pakkoavioliittotyyppi käsittää tapaukset, joissa Suomessa asuva Suomen kansalainen solmii yhteisymmärryksessä liiton ulkomaalaisen naisen kanssa. Alun yhteisymmärryksestä huolimatta ulkomainen vaimo joutuu liitossa hyväksikäytetyksi, eikä hänellä ole alistamisen seurauksena tosiasiallista mahdollisuutta lopettaa avioliittoa. ${ }^{15}$ Huomionarvoista tässä luokittelussa on jokaisen tyypin kytkös ulkomaille - kantasuomalaisten välisiä pakkoavioliittoja ei selvityksessä ilmennyt, mikä ei kuitenkaan sulje pois niiden mahdollisuutta.

Pakkoavioliittojen yleisyyttä Suomessa on vaikea arvioida monestakin syystä. Vain osa niistä tulee viranomaisten tietoon eivätkä viranomaiset tai järjestöt ole pitäneet näistäkään tapauksista tilastoja. Lisäksi osa pakkoavioliitoista on solmittu siten uskonnollisin menoin, ettei Suomen oikeusjärjestelmä edes tunnusta niitä avioliittoina. ${ }^{16}$ Pakkoavioliitot näkyvät kuitenkin järjestöjen työssä, ja näiden arviot auttavat antamaan osviittaa ilmiön esiintymisestä Suomessa. Esimerkiksi Monika-Naiset liitto ry:llä on pitkä historia tuki- ja kriisipalveluiden tarjoajana maahanmuuttajanaisille ja heidän lapsilleen. Vuonna 2015 liiton tietoon tuli 25 pakkoavioliittotapausta, ja vuonna 2016 tämä lukumäärä saavutettiin jo kevään aikana. ${ }^{17}$ Lisääntyneen maahanmuuton myötä ilmiö vaikuttaakin olevan jatkuvasti yleistymässä myös Suomessa. ${ }^{18}$ Varmoja johtopäätöksiä ei kuitenkaan voida vetää. Asiassa on otettava huomioon muun muassa "kunniaan"19 liittyvää väkivaltaa koskeva uutisointi ja lisääntynyt julkinen keskustelu, jotka saattavat auttaa nostamaan tapauksia myös viranomaisten ja järjestöjen tietoon. Luonnollisesti vain osa tapauksista tulee ylipäätään esille.

Kriminologian ja oikeuspolitiikan instituutin laatimasta selvityksestä ilmenee, että vaikka järjestöt ja suorittavat viranomaiset työskentelevät pakkoavioliittojen parissa, ei tapauksia juuri ilmene rikosprosessissa. Tieto tapauksista ei myöskään välity sujuvasti viranomaisten välillä. Selvityksessä hyödynnettiin poliisi-ja tuomioistuintilastoja tapauksista, joissa ilmoitettu tai tuomittu teko oli ollut jokin kolmesta vaihtoehdosta, joina avioliittoon pakottaminen voi

15 Toivonen 2017, s. 9

16 Hansen 2016.93

17 Monika-Naiset liitto ry 17.6.2016.

18 Maniken ym. 2016, s. 79.

18 Hansen ym. 2016, s. 79.

Käytän termiä "kunnia" lainausmerkeissä johtuen sen kyseenalaisesta merkityksestä. Kaiken kaikkiaan "kunniaan" liittyvässä väkivallassa on nähdäkseni kyse patriarkaalisesta kunniakäsityksestä ja ennen kaikkea väkivallasta etenkin naisia kohtaan. Uhrin syyllistäminen ja väkivallan verhoaminen kulttuurisidonnaiseen kunniakäsitykseen ei tee oikeutta uhreille. Ks. aiheesta esim. Gill, Aisha: Honor Killings and the Quest for Justice in Black and Minority Ethnic Communities in the United Kingdom. United Nations 2009 tällä hetkellä tulla Suomessa tuomituksi. Nämä ovat ihmiskauppa, törkeä ihmiskauppa ja pakottaminen, joihin palataan myöhemmin. Tilastojen perusteella avioliittoon pakottamista koskevia tapauksia on ollut vain muutamia viime vuosina. ${ }^{20}$ Kuten sanottua, järjestöt ja muut tahot kohtaavat avioliittoon pakottamista kuitenkin huomattavasti enemmän. Näin ollen ilmiön esiintyminen rikosprosessissa on räikeässä epäsuhteessa sen tosiasialliseen esiintymiseen Suomessa.

\section{PAKKOAVIOLIITTO IHMISOIKEUSLOUKKAUKSENA}

Suomen perustuslain (731/1999) 22 §:n mukaan julkisen vallan on turvattava perusoikeuksien ja ihmisoikeuksien toteutuminen myös yksityisten toimijoiden välisissä suhteissa. Avioliittoon pakottaminen itsessään on määritelty ihmisoikeusloukkaukseksi useissa kansainvälisissä instrumenteissa, ja se loukkaa useita oikeudellisesti turvattuja oikeushyviä. Istanbulin sopimuksen kohteena on naisiin kohdistuva väkivalta, jonka muodoksi avioliittoon pakottaminen lukeutuu. Kansainvälisen työjärjestö ILO:n mukaan noin 13 miljoonaa, eli 84 \% kaikista pakkoavioliiton uhreista oli naisia tai tyttöjä vuonna 2016. ${ }^{21}$ Siten avioliittoon pakottaminen loukkaa oikeutta yhdenvertaiseen kohteluun ja miesten ja naisten väliseen tasa-arvoon.

Pakkoavioliitto loukkaa myös yksityiselämän suojaa. Suojan piiriin kuuluu oikeus yksityiselämään kodissa, ihmissuhteiden luomiseen kodin ulkopuolella, perhe-elämään sekä oikeus määrätä itsestään ja ruumistaan. ${ }^{22}$ Avioliiton merkitys yksityiselämän kannalta on kiistaton, ja siihen pakottaminen loukkaa henkilön autonomiaa vakavasti. Myös loukkauksen ajallinen kesto on merkittävä - vastentahtoinen liitto voi kestää kauankin. Pitkäaikainen pakkoavioliitto voi johtaa tilanteeseen, jossa rajoitetaan yksilön oikeutta päättää paitsi avioitumisesta myös seksuaalisuudestaan ja lasten hankkimisesta. Lisäksi avioliittoon pakottaminen voi loukata myös yksilön oikeutta koulutukseen ja työntekoon.

Loukkauksen kohteena on myös oikeus henkilökohtaiseen vapauteen ja koskemattomuuteen. Toivonen kuvaa avioliittoon pakottamiseen liittyvää monenlaista väkivaltaa. Väkivalta voi olla niin fyysistä, taloudellista kuin henkistäkin. Ilmiölle on ominaista myös se, että uhriin kohdistuva uhka on usein luonteeltaan kollektiivista, eli painostamassa voi olla esimerkiksi koko lähiyhteisö. Lisäksi pakottamalla solmitussa avioliitossa luodaan pohja mahdolliselle jatkuvalle väkivallalle liiton kestäessä, sillä liitto ei lähtökohtaisesti perustu molemminpuoliseen kunnioitukseen vaan vallankäyttöön. Myös avioliiton lopettaminen voi olla uhrille vaarallista. ${ }^{23}$

20 Toivonen 2017, s. 3, 6. Poliisille tehtyjä rikosilmoituksia tarkasteltiin ajalta 1.1.2015-31.12.2016 ja tuomioistuintilastoja ajalta 1.5.2013 - 31.12.2016. Toivonen kuitenkin huomauttaa, ettei esimerkiksi seksuaalirikoksia koskevia ilmoituksia tutkittu selvityksessä, vaikka myös näissä voisi avioliittoon pakottaminen tulla ilmi.

21 Global estimates of modern slavery: forced labour and forced marriage 2017, s. 45

22 HE 309/1993 vp, s. 52-53.

23 Toivonen 2017, s. 9-14. 
Mannerheimin Lastensuojeluliiton Amoral-hankkeen loppujulkaisussa annetaan esimerkkejä erilaista pakkoavioliiton muodoista. Usein vaikuttimina ovat taloudelliset syyt sekä kunniakäsitykset. Karuimmillaan pakkoavioliitossa voi kuitenkin olla kyse siitä, että raiskattu nainen pakotetaan avioitumaan raiskaajansa kanssa suvun "kunnian" säilyttämiseksi. ${ }^{\mathbf{2 4}}$ Ihmisarvon loukkaamattomuus voi siten myös olla pakkoavioliittotilanteissa vaarassa.

Oikeus solmia avioliitto ja perustaa perhe on turvattu monissa kansainvälisissä inmisoikeusnormistoissa. Avioliittoa tutkineen Maja Kirilova Erikssonin mukaan tämä synnyttää valtioille sekä negatiivisen että positiivisen velvoitteen: valtioiden tulee yhtäältä pidättäytyä toimista, jotka voisivat loukata oikeutta avioliittoon, ja toisaalta aktiivisin toimin edistää tämän oikeuden toteutumista. Tämä ei Erikssonin mukaan kuitenkaan tarkoita sitä, että valtiot voisivat asettaa yksilöille velvollisuuden mennä naimisiin. ${ }^{25}$ Valtioiden tulee turvata yksilön oikeus solmia avioliitto, ja vaikka avioitumispäätöksen motiivina voi olla muutakin kuin rakkaus, pakkoavioliitto on aina ristiriidassa suhteessa henkilön oikeuteen avioitua. Pakkoavioliittoa ei koskaan solmita henkilön sisäisistä motiiveista käsin, vaan kyseessä on ulkopuolelta tuleva velvollisuus, joka estää yksilön oikeuden vapaan käytön.

Pakkoavioliitot voivat olla myös orjuuden muoto. Orjuus on kielletty useissa kansainvälisissä sopimuksissa, kuten Kansalaisoikeuksia ja poliittisia oikeuksia koskevassa kansainvälisessä yleissopimuksessa (SopS 8/1976). Modernia orjuutta tutkiva Jean Allain esittää, että pakkoavioliitossa on kyse orjuudesta silloin, kun henkilö on toisen lähes täydellisessä kontrollissa siten, että se mahdollistaa tämän hyväksikäytön. Kyseessä on omistussuhde, jossa uhrin henkilökohtainen autonomia ja vapaa tahto on evätty siten, että häntä kohdellaan kuin omaisuutta. Näin ollen häntä voidaan käyttää hyväksi niin seksuaalisesti, taloudellisesti kuin työvoimana puolisoiden kodissa. ${ }^{26}$ Myös kansainvälinen työjärjestö ILO on modernia orjuutta koskevassa raportissaan luokitellut pakkoavioliitot orjuuden muodoksi. Raportin mukaan vuonna 2016 kaikista modernin orjuuden uhreista $71 \%$ oli naisia ja tyttöjä. ${ }^{27}$

\section{ISTANBULIN SOPIMUS JA SUOMEN KANSALLINEN LAIN. SÄÄDÄNTÖ}

\section{I Suomen liittyminen Istanbulin sopimukseen}

Suomi allekirjoitti Euroopan neuvoston yleissopimuksen naisiin kohdistuvan väkivallan ja perheväkivallan ehkäisemisestä ja torjumisesta (Istanbulin sopimus, CETS n:o. 210) vuonna 2011, ja se tuli voimaan Suomessa 1.8.2015. Sopimus sisältää määräykset naisiin kohdistuvan

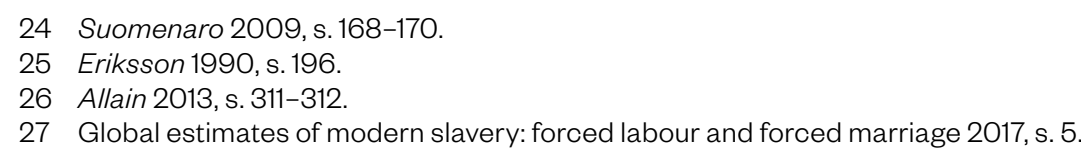

väkivallan sekä perheväkivallan ehkäisemisestä ja poistamisesta, väkivallan uhrien suojelemisesta sekä väkivallan tekijöiden saattamisesta edesvastuuseen teoistaan. Sopimuksen johdanto-osassa todetaan, että naisiin kohdistuva väkivalta sukupuoleen perustuvana on yksi ratkaisevista yhteiskunnallisista rakenteista, joilla naiset asetetaan alistettuun asemaan miehiin verrattuna. Sitä pidetään myös historiallisena tekijänä, joka on osaltaan estänyt naisten täysmittaista etenemistä. ${ }^{\mathbf{2 8}}$ Istanbulin sopimuksen 5 artikla velvoittaa jäsenvaltioita pidättymään osallistumasta naisiin kohdistuviin väkivallantekoihin, sekä varmistamaan, että näin tekevät myös niiden puolesta toimivat tahot. Samassa artiklassa asetetaan valtioille huolellisuusvelvoite turvata oikeuksien toteutuminen myös ei-valtiollisten toimijoiden välisissä suhteissa toteuttamalla tarvittavat lainsäädäntö- ja muut toimet.

\subsection{Pakkoavioliiton kriminalisointivelvoite - $\mathbf{3 7}$ artikla}

Jo sopimuksen johdannossa pakkoavioliitto asetetaan rinnasteiseen asemaan muun muassa raiskausten ja sukuelinten silpomisen kanssa, mikä kuvastaa ilmiön vakavuutta. ${ }^{29}$ Sopimuksessa siihen pyritään puuttumaan siviilioikeudellisesti varmistamalla uhreille mahdollisuus avioliiton purkamiseen tai mitätöintiin ilman kohtuutonta taakkaa. 37 artikla asettaa myös nimenomaisen pakkoavioliiton kriminalisointivelvoitteen:

"Osapuolet toteuttavat tarvittavat lainsäädäntö- tai muut toimet varmistaakseen, että aikuisen tai lapsen tahallinen pakottaminen avioliittoon säädetään rangaistavaksi.

Osapuolet toteuttavat tarvittavat lainsäädäntö- tai muut toimet varmistaakseen, että aikuisen tai lapsen tahallinen houkutteleminen muun kuin sen osapuolen tai valtion alueelle, jossa hän asuu, tarkoituksena pakottaa hänet avioliittoon säädetään rangaistavaksi.",30

Istanbulin sopimuksen selitysmuistiossa pakottamisella tarkoitetaan fyysistä ja psykologista voimankäyttöä, jossa käytetään pakkoa. Rikos on viety loppuun, kun avioliitto on solmittu siten, että vähintään toinen osapuoli ei ole vapaaehtoisesti suostunut siihen, vaan hänet on siihen pakotettu. Selitysmuistiossa todetaan myös monien pakkoavioliiton uhrien joutuvan

28 Euroopan neuvoston yleissopimus naisiin kohdistuvan väkivallan ja perheväkivallan ehkäisemisestä ja torjumisesta, s. 3.

29 Euroopan neuvoston yleissopimus naisiin kohdistuvan väkivallan ja perheväkivallan ehkäisemisestäja torjumisesta, s. 3-4: "Euroopan neuvostonjäsenvaltiot ja muut tämän yleissopimuksen allekirjoittajat, jotka - tiedostavat syvästi huolostun ja että naiset ja tytöt altistuvat usein vakaville väkivalla jotka - tick "kunnon" nimissa tehtablle vakivalleja sukuelinten ja tyttijen" nis ja tyttöjen ihmisoikeuksia ja estävät olennaisesti naisten ja miesten välisen tasa-arvon saavuttamista". 30 Euroopan neuvoston yleissopimus naisiin kohdistuvan văkivallan ja perhevăkivallan ehkäisemisest ja torjumisesta, s. 14. Paitsi avioliiton purkamissääntelyllä ja pakottamisen kriminalisoinnilla, pyritään yleissopimuksessa parantamaan uhrien asemaa pakkoavioliittotapauksissa myös kotipaikka- ja oleskelulupa-asioita koskevilla määräyksillä. 
ensin toiseen valtioon, jossa heidät pakotetaan naimisiin kyseisen valtion asukkaan kanssa. Tästä johtuen sopimuksessa on haluttu kriminalisoida paitsi avioliittoon pakottaminen, myös uhrin houkutteleminen toiseen valtioon tässä tarkoituksessa. ${ }^{31}$ Näin tapahtuu Ihmisoikeusliiton haastatteluaineiston perusteella valtaosa Suomea koskettavista pakkoavioliitoista. ${ }^{32}$ Edellä kuvattu tunnusmerkistö voi täyttyä, vaikkei avioliittoa solmittaisi. Houkuttelemisella tarkoitetaan mitä tahansa käytöstä, jolla tekijä houkuttelee uhrin matkustamaan toiseen valtioon tarkoituksenaan pakottaa tämä avioliittoon. Selitysmuistiossa mainitaan esimerkkinä sukulaisten tapaaminen tekosyynä matkalle. Tahallisuuden on katettava sekä uhrin houkutteleminen ulkomaille että tarkoitus pakottaa uhri siellä avioliittoon. Selitysmuistiossa nostetaan esiin tarve säätää tällainen toiminta rangaistavaksi jäsenvaltioiden rikoslaissa, jotta otetaan huomioon muissa oikeudellisesti sitovissa kansainvälisissä instrumenteissa asetetut standardit. ${ }^{33}$

\subsection{Virallisen syytteen alaisuus - 55 artikla}

Istanbulin sopimuksen 55 artikla koskee asianosaisen vireille panemia ja viran puolesta vireille pantavia oikeudenkäyntejä. Siinä asetetaan osapuolille velvollisuus varmistaa, ettei esimerkiksi pakkoavioliittotapausten tutkinta tai syytteeseenpano riipu kokonaan uhrin rikosilmoituksesta tai muusta ilmoituksesta, mikäli rikos on tehty kokonaan tai osittain tämän jäsenvaltion alueella. Lisäksi artiklassa velvoitetaan varmistamaan oikeudenkäynnin jatkamisen mahdollisuus, vaikka uhri peruuttaisi lausuntonsa tai ilmoituksensa. ${ }^{34}$ Sopimuksessa on näin huomioitu uhrin riippuvainen asema tekijästä tietyissä rikostyypeissä, joihin lukeutuvat muun muassa pakkoavioliitto ja naisten sukuelinten silpominen. Näissä rikoksissa tekijänä on usein uhrin lähiomainen, ja kynnys syytteen nostamiseen voi olla korkea. Tähän problematiikkaan perehdytään tarkemmin erilliskriminalisoinnin hyötyjä ja haittoja punnittaessa luvussa 5 .

Velvollisuutta asettaa tietyt teot yleisen syytteen alaisiksi käsitellään myös hallituksen esityksessä eduskunnalle naisiin kohdistuvan väkivallan ja perheväkivallan ehkäisemisestä ja torjumisesta tehdyn Euroopan neuvoston yleissopimuksen hyväksymisestä sekä laeiksi yleissopimuksen lainsäädännön alaan kuuluvien määräysten voimaansaattamisesta, rikoslain 1 luvun 11 §:n muuttamisesta ja ulkomaalaislain 54 §:n muuttamisesta (HE 155/2014 vp). Esityksessä kiinnitetään huomiota siihen, ettei syytteeseenpano saa riippua kokonaan uhrin rikosilmoituksesta. Näin ollen

31 Explanatory report CETS 210, s. 34: "The term "forcing" refers to physical and psychological force where coercion or duress is employed. The offence is complete when a marriage is concluded to which at least one party has - due to the above circumstances - not voluntarily consented to." Suomen kielen sana vuvasta täydellisesti niitä sävyeroja, jotka sanoilla "coercion" ja "duress" on. Alkuperäisteksti sisältää siten niin varsinaisen pakottamisen kuin tietynlaisen pakkotilan

32 Hansen ym. 2016, s. 84.

33 Explanatory report CETS 210, s. 34

34 Euroopan neuvoston yleissopimus naisiin kohdistuvan väkivallan ja perheväkivallan ehkäisemisestä ja torjumisesta, s. 19. velvoitteen virallisen syytteen alaisuudesta ei katsota olevan täysin ehdoton. ${ }^{35}$ Tämä kanta näkyy seuraavaksi käsiteltävässä Suomen kansallisessa lainsäädännössä.

\subsection{Kansallisen lainsäädännön lähtökohtia}

Pakkoavioliittoa ei ole Istanbulin sopimuksen velvoitteista huolimatta nimenomaisesti kriminalisoitu Suomessa. Sopimuksen implementointia koskevissa kansallisissa esitöissä todetaan, ettäSuomenlainsäädäntökattaajoentuudestaan 37 artiklankriminalisointivaatimuksen. Perusteluissa todetaan avioliittoon pakottamisen voivan täyttää ihmiskaupan tunnusmerkistön ja olevan siten jo rangaistavissa. Näin ollen ihmiskaupan kriminalisoinnin katsotaan olevan riittävä toimi sopimusvelvoitteiden täyttämiseksi, mutta artiklaa koskevien perusteluiden lopussa nostetaan kuitenkin esille mahdollinen tarve myöhemmin harkita, onko lainsäädännön tarkemmalle arvioimiselle tarvetta. Tässä viitataan Ruotsiin, Englantiin ja Walesiin, joissa lainsäädäntöön on lisätty pakkoavioliittoa koskeva rangaistussäännös. ${ }^{36}$

Rikoslaki mahdollistaa tällä hetkellä avioliittoon pakottamisesta tuomitsemisen ihmiskauppana, törkeänä inmiskauppana tai pakottamisena. Istanbulin sopimusta ratifioitaessa rikoslakiin sisällytettiin pakottamisen yhteyteen maininta avioliittoon pakottamisesta, mutta itsenäistä rikosnimikettä ei luotu. ${ }^{37}$ Seuraavaksi tarkastellaan ensin ihmiskauppalainsäädäntöä suhteessa pakkoavioliittoihin, sitten pakottamissääntelyn soveltumista ja lopuksi esitetään vielä lyhyt huomio kaksoisrangaistavuudesta.

\subsection{Ihmiskauppalainsäädännön soveltuminen}

Ihmiskauppa kielletään rikoslain 25 luvun $3 \S: s s a ̈$. Tiivistetysti säännöksen mukaan ihmiskaupasta tuomitaan muun ohella se, joka käyttämällä hyväkseen toisen riippuvaista asemaa tai painostamalla ottaa toisen määräysvaltaansa tai luovuttaa hänet hänen saattamisekseen parituksen tai siihen rinnastettavan seksuaalisen hyväksikäytön kohteeksi tai muihin ihmisarvoa loukkaaviin olosuhteisiin. Törkeää inmiskauppaa koskee saman luvun 3 a §, jonka mukaisesti tekoa voidaan pitää törkeänä muun muassa mikäli 3 §:ssä mainittujen keinojen sijasta tai lisäksi käytetään väkivaltaa, uhkausta tai kavaluutta ja rikos on myös kokonaisuutena arvostellen törkeä. Kuten edellä on todettu, lainsäätäjä katsoi Istanbulin sopimusta voimaan saatettaessa (HE 155/2014 vp) tämän sääntelyn kattavan myös avioliittoon pakottamisen, eikä nähnyt siten tarvetta pakkoavioliiton erilliskriminalisoinnille. Kuitenkin Ihmisoikeusliitto

35 HE 155/2014 vp, s. 66. Perusteluna vedotaan vuonna 2007 tehtyyn lasten seksuaalisen riiston ja seksuaalisen hyväksikäytön torjumista koskevassa Euroopan neuvoston yleissopimukseen (CETS 201), jossa on samankaltainen määräys, mutta josta puuttuu sana "kokonaan". Näin ollen tämän nähdään olevan tiukempi velvoite, kuin mikä Istanbulin sopimuksessa osapuolille asetetaan.

36 HE 155/2014 vp, s. 51-52.

37 Oikeusministeriö 18.10 .2017 
arvioi sääntelyn olevan tällä hetkellä puutteellista ja soveltamisen olevan hankalaa. ${ }^{38}$ Samaan lopputulokseen päätyi myös Toivonen oikeusministeriön pyynnöstä tekemässään selvityksessä. Ihmiskaupan tunnusmerkistöä pidetään monimutkaisena, eikä pykälän katsota kattavan kaikkia pakkoavioliittotapauksia. ${ }^{39}$ Seuraavaksi tarkastellaan tarkemmin eriäviä mielipiteitä herättävää inmiskauppalainsäädännön soveltamisalaa.

Ihmiskauppasääntelyä on perusteltu yksityiskohtaisesti hallituksen esityksessä eduskunnalle laiksi rikoslain muuttamisesta ja eräiksi siihen liittyviksi laeiksi (HE 34/2004 vp). Pykälää koskevissa perusteluissa painotetaan korkeaa tahallisuusvaatimusta: tahallisuuden on katettava kaikki säännöksen osatekijät, eli keinot, tekotavat ja tarkoitus. Tekijän tarkoituksena on täytynyt nimenomaisesti olla uhrin saattaminen ihmisarvoa loukkaaviin olosuhteisiin. ${ }^{\mathbf{4 0}}$ Pakkoavioliittotapauksissa lainsäätäjän asettama vaatimus keinoista, eli esimerkiksi toisen riippuvaisen aseman hyväksikäyttö, täyttynee melko usein, sillä monesti tekijänä ovat uhrin lähisukulaiset. Myös tekotavat, eli esimerkiksi uhrin ottaminen valtaan, luovuttaminen tai kuljettaminen vaikuttavat Ihmisoikeusliiton suorittamien haastattelujen perusteella toteutuvan monessa tapauksessa. ${ }^{41}$ Ongelmalliseksi ihmiskauppalainsäädännön soveltumisessa näyttääkin muodostuvan tahallisuus teon tarkoituksen suhteen. Rikoslain 25 luvun 3 §:n 1 momentin teon tarkoitusta koskeva kohta kuuluu: "- - hänen saattamisekseen 20 luvun 9 §:n 1 momentin 1 kohdassa tarkoitetun tai siihen rinnastettavan seksuaalisen hyväksikäytön kohteeksi, pakkotyöhön tai muihin ihmisarvoa loukkaaviin olosuhteisiin taikka elimien tai kudoksien poistamiseksi - -". Teon tarkoituksen arvioinnissa tulee muistaa edellä esitetty tahallisuuden vaatimus: tekijän tarkoituksena on nimenomaisesti pitänyt olla uhrin saattaminen ihmisarvoa alentaviin olosuhteisiin. Tämä tarkoitusta koskeva tahallisuuden vaatimus muodostuukin Toivosen selvityksen mukaan usein ihmiskauppalainsäädännön soveltamisen kompastuskiveksi. Vanhemmat tai lähisukulaiset kokevat usein toimivansa uhrin parhaaksi valitessaan tälle mielestään sopivimman kumppanin eikä tahallisuuden vaatimus siten täyty. ${ }^{\mathbf{4 2}}$

Asiaa koskevissa hallituksen esityksissä nostetaan kuitenkin esiin vastakkainen kanta. Jo tahallisuus koskien pelkkää tarkoitusta saattaa toinen pakkoavioliittoon voi riittää, sillä pakkoavioliitot ovat tietyin edellytyksin katsottavissa itsessään ihmisarvoa loukkaaviksi olosuhteiksi. Ihmiskauppasäännöstä lakiin kirjattaessa näkemys oli vielä varsin suppea, eikä rikosnimikkeen perusteluissa juuri pohdittu soveltamista pakkoavioliittoihin. Hallituksen esityksessä katsotaan, että käsite ihmisarvoa loukkaava olosuhde on sidoksissa kulloiseenkin ajankohtaan ja kulttuuriin. Tällaisina olosuhteina voidaan perusteluiden mukaan pitää ainakin niitä orjuuteen verrattavia järjestelmiä ja käytäntöjä, jotka on mainittu Yhdistyneiden kansakuntien

$$
\begin{aligned}
& 38 \text { Hansen ym. 2016, s. } 20 . \\
& 39 \text { Toivonen 2017, s. } 16 . \\
& 40 \text { HE 34/2004 vp, s. } 93 . \\
& 41 \text { Hansen ym. } 2016 \text { s. 84-86. }
\end{aligned}
$$

42 Toivonen 2017, s. 16 lisäsopimuksessa orjuuden, orjakaupan ja orjuuteen verrattavien järjestelmien ja käytännön tukahduttamisesta (SopS 17/1959). Orjuuteen verrattavia ovat kyseisen sopimuksen 1 artiklan c-kohdassa mainitut pakkoavioliiton muodot. ${ }^{\mathbf{4 3}}$ Näin ollen ihmiskauppaa koskevan pykälän valmistelussa pakkoavioliitot on mainittu lähinnä sivulauseessa, eikä varsinaista soveltamista ilmiöön ole tarkemmin pohdittu.

Esitöiden tekstissä ei myöskään avattu, mitä nämä viitatut pakkoavioliiton muodot ovat. Lisäsopimuksessa orjuuteen rinnastetaan seuraavat avioliittokäytännöt: 1) nainen pakotetaan avioliittoon muulle henkilölle tai henkilöryhmälle suoritettavaa raha- tai luontaissuoritusta vastaan tai 2) aviomiehellä tai tämän sukulaisilla on oikeus luovuttaa nainen kolmannelle tai 3) nainen voidaan luovuttaa perintönä kolmannelle aviomiehen kuoleman jälkeen. ${ }^{44}$ Näitä edellytyksiä tutkiessa voidaan todeta, etteivät ne kata kaikkia pakkoavioliittoja. Esimerkiksi naisen vastikkeeton luovutus perheeltä aviomiehelle ei tulisi sääntelyn piiriin. Tämän aukollisuuden huomasi myös lainsäätäjä Istanbulin sopimusta ratifioidessaan. Näin ollen vuonna 2014 laaditussa sopimuksen voimaansaattamista koskevassa hallituksen esityksessä myös muunlaisten pakkoavioliiton muotojen katsottiin kuuluvan sääntelyn piiriin, kunhan tunnusmerkistön vaatimus keinoista ja tekotavasta täyttyvät. ${ }^{45}$

Hallituksen esityksessä puhutaan muunlaisista pakkoavioliiton muodoista, muttei kaikista muodoista. Voidaan kysyä, mitä kaikkea sääntely siis lopulta kattaa. Tähän ei saada vastausta asiasta lausuneen työelämä-ja tasa-arvovaliokunnan mietinnöstä ${ }^{46}$ eikä hallituksen esityksessä viitatusta inmiskauppatyöryhmän mietinnöstä ${ }^{47}$. Kenties sanamuoto on jätetty tarkoituksella avoimeksi, sillä inmisarvoa loukkaavan olosuhteen katsotaan kuten sanottua riippuvan ajankohdasta ja kulttuurista. Vaikuttimena voisi olla myös lähdemateriaalissa korostuva tiedon puute; rajauksia on vaikea tehdä, jollei tarkalleen tiedä, mitä muotoja on olemassa. Vaikuttaa siltä, että ajan kuluessa säädöksen soveltamisalaa on uusien esitöiden avulla pyritty laajentamaan alkuperäisestä tarkoituksesta ja sekin on tehty melko epätäsmällisesti.

Tällainen soveltamisalan laajentaminen voidaan nähdä ongelmalliseksi suhteessa Suomen perustuslain 1 luvun 8 §:ssä säädettyyn rikosoikeudelliseen laillisuusperiaatteeseen: rangaistavan teon tulee olla tekohetkellä säädetty laissa rangaistavaksi. Rikoslain 3 luvun $1 \S$ :ään laillisuusperiaate on kirjattu vielä tarkemmin: teon tulee olla tekohetkellä laissa nimenomaan säädetty rangaistavaksi. Tähän vaatimukseen sisältyy epätäsmällisyyskielto, jonka mukaisesti kriminalisoinnin tulee olla riittävän selkeä, jotta lakia lukemalla on ennakoitavissa

43 HE 34/2004 vp, s. 97

44 SopS $17 / 1959$

45 HE 155/2014 vp, s. 51. Tarkka muotoilu kuuluu:"Ihmisarvoa loukkaaviin olosuhteisiin saattamisena voidaan inmiskauppasäännöksen tarkoittamalla tavalla pitää myös muunlaisia pakkoavioliton muotoja, kunha ihmiskauppasäännöksen muut edellytykset, eli jokin mainituista keinoista ja tekotavoista, täyttyvät."

46 TyVM 15/2014 vp.

47 Oikeusministeriön julkaisu 63/2012 
teon rangaistavuus. Tällä hetkellä pakkoavioliiton rangaistavuus on luettavissa esitöiden muutoksissa, mitä ei voida pitää riittävänä. Sekä Ihmisoikeusliiton että Toivosen selvityksessä haastatellut korostavatkin lainsäädännön vaikeaselkoisuutta, mikä vaikeuttaa pakkoavioliittoihin puuttumista. ${ }^{48}$

Sääntelyn soveltumisen arvioinnissa on pantava merkille myös syyteoikeus. Laki oikeudenkäynnistä rikosasioissa (689/1997) asettaa 1 luvun 6 §:ssä syyttäjälle ensisijaisen syyteoikeuden. Antti Jokela katsoo Suomen oikeusjärjestelmässä olevan edelleen pääsääntönä legaliteettiperiaate eli syytepakkoperiaate, vaikka myös syyteharkintaperiaate voi tulla sovellettavaksi. ${ }^{49}$ Ihmiskauppa on rikoslain 25 luvun mukaan virallisen syytteen alainen rikos. Näin ollen syyttäjällä on syytekynnyksen ylittyessä velvollisuus nostaa syyte. Tällöin asianomistajan halulla käynnistää rikosprosessi ei ole merkitystä. Tätä avioliittoon pakottamisen virallisen syytteen alaisuutta punnitaan erilliskriminalisoinnin hyötyjä ja haittoja käsittelevässä osiossa.

\subsection{Pakottamisen tunnusmerkistön soveltuminen}

Pakottamisen kieltävän rikoslain 25 luvun 8 § mukaan:

"Joka oikeudettomasti väkivallalla tai uhkauksella pakottaa toisen tekemään, sietämään tai tekemättä jättämään jotakin, on tuomittava, jollei teosta muualla laissa säädetä ankarampaa rangaistusta, pakottamisesta sakkoon tai vankeuteen enintään kahdeksi vuodeksi."

Rikoslain kokonaisuudistuksen yhteydessä tarkistettiin myös pakottamisen tunnusmerkistöä. Hallituksen esityksessä eduskunnalle rikoslainsäädännön kokonaisuudistuksen toisen vaiheen käsittäviksi rikoslain ja eräiden muiden lakien muutoksiksi väkivallan tai uhkauksen vaatimuksen katsottiin käsittävän monenlaiset oikeudettomat painostuskeinot, kuten taloudelliset keinot. Hallituksen esityksen mukaan vaadittu oikeudettomuus koskee tätä pakotuskeinoa, sitä mihin pakotetaan tai näiden suhdetta. Pakkoavioliittojen kannalta merkille pantavaa on perustelujen seuraava kohta:

"Rajat riippuvat siitä, mitkä keinot kulttuurimme toisen tahdon taivuttamiseksi missäkin asiassa hyväksyy. On huomattavan paljon sellaista painostusta, esimerkiksi lapsien ja vanhempien välisissä suhteissa, jota ei pidetä oikeudettomana pakottamisena." 50

48 Ks. esim. Hansen ym. 2016, s. 90 ja Toivonen 2017, s. 16

49 Jokela 2008, s. 211

50 HE 94/1993 vp, s. 111.
Tämä osoittaa rajanvedon kulttuurisidonnaisuuden; vaikka hyväksyttävän painostuksen ja hyväksyttävien päämäärien rajat voivat näyttäytyä erilaisina tekijän ja uhrin kulttuuritaustasta riippuen, lienee selvää, ettei suomalainen kulttuuri hyväksy avioliittoon pakottamista. ${ }^{\mathbf{5 1}}$

Pakottaminen on rikoslain 25 luvun 9 §:ssä säädetty asianomistajarikokseksi. Syyttäjä ei siten saa nostaa siitä syytettä, ellei asianomistaja ilmoita sitä syytteeseen pantavaksi. Pääsäännöstä poiketaan, mikäli pakottamisessa on käytetty hengenvaarallista välinettä tai erittäin tärkeä yleinen etu vaatii nostamaan syytteen. Toivosen mukaan pakottaminen voi yhteisöllisessä kontekstissa olla paljon muutakin kuin fyysistä pakottamista. Keinot voivat olla hienovaraisia ja abstrakteja. ${ }^{\mathbf{5 2}}$ Tällöin syyttäjälle ei muodostu itsenäistä syyteoikeutta. Hongin mukaan soveltamiskäytännön valossa pakottamissääntely edustaakin pitkälti perinteistä tekorikosoikeudellista ajattelua, johon liittyvää problematiikkaa käsitellään tarkemmin jäljempänä. Näin ollen yksittäisen teon tulee lähtökohtaisesti täyttää laissa asetetut edellytykset ollakseen rangaistava. Pakkoavioliittotapauksissa yksittäinen pakottamiseen liittyvä teko ei välttämättä kuitenkaan riitä täyttämään rangaistavuudelle asetettavia vaatimuksia. Tekoa tulisikin Hongin mielestä tutkia osana kontekstia ja pidempää jatkumoa, jonka kokonaisuuden summana yksilö päätyy vasten tahtoaan avioliittoon. ${ }^{\mathbf{5 3}}$

Lisäksi tulee ottaa huomioon, että edellä käsitelty Istanbulin sopimuksen 55 artikla edellyttää, ettei syytteen nostamisen tule riippua kokonaan uhrin rikosilmoituksesta. Mikäli avioliittoon pakottamista arvioidaan pakottamissäännöksen nojalla, on lähtökohtana asianomistajan velvollisuus nostaa syyte. Näin ollen voidaan argumentoida kansallisen säännöksen soveltamisen olevan ristiriidassa artiklan tarkoituksen kanssa. Sana kokonaan nousee tästä näkökulmasta katsottuna merkittäväksi. Sovellettavaksi voi edellä esitetyn mukaisesti tulla myös ihmiskauppalainsäädäntö ja pakottaminenkin voi tietyissä tapauksissa kuulua virallisen syytteen alaisuuteen, joten syytteen nostaminen ei kokonaan riipu uhrin toimista.

\subsection{Kaksoisrangaistavuudesta}

Kaksoisrangaistavuuden vaatimuksella tarkoitetaan rikoslain 1 luvun 11 §:ssä sitä, että vieraan valtion alueella tehtyyn rikokseen voidaan soveltaa Suomen lakia vain, mikäli rikos on myös tekopaikan lain mukaan rangaistava ja siitä olisi voitu tuomita rangaistus myös kyseisen maan tuomioistuimessa. Tästä pääsäännöstä on kuitenkin useita poikkeuksia. Istanbulin sopimuksen selitysmuistion mukaan puutteet lainsäädännössä ja resursseissa sekä haluttomuus tutkia voivat muodostaa esteen naisten oikeuksien toteutumisessa osassa valtioista, joissa teot tapahtuvat.

Ks. tästä esim Oikeusministeriö 18102017

52 Toivonen 2017, s. 13

53 Hong 2017, s. 385. 
Näin ollen sopimuksessa edellytetään mahdollisuutta syyttää ja rangaista jäsenvaltioissa näistä teoista, vaikkei niitä olisi tekovaltiossa säädetty rangaistaviksi. ${ }^{\mathbf{5 4}}$

Ihmiskauppa luokitellaan kansainväliseksi rikokseksi rikoslain 1 luvun 7 §:ssä, joten Suomen lakia voidaan soveltaa myös Suomen ulkopuolella tehtyyn rikokseen tekopaikan laista riippumatta. Sen sijaan pakottamista koskee pääperiaatteena edellä esitetty kaksoisrangaistavuuden vaatimus. Istanbulin sopimuksen voimaansaattamisessa lausuntovaliokuntana toiminut eduskunnan työelämä- ja tasa-arvovaliokunta nosti tämän ongelman esiin mietinnössään (TyVM 15/2014 vp) ja esitti kaksoisrangaistavuuden vaatimusta koskevan rikoslain 1 luvun 11 §:ään lisättävän viittauksen avioliittoon pakottamisesta. ${ }^{\mathbf{5 5}}$ Lisäys tehtiin, minkä johdosta tekovaltion lainsäädäntö tai sen puute ei vaikuta myöskään pakottamissääntelyn soveltamiseen. Soveltamisongelmat viriävätkin muista syistä, kuten edellä luvuissa 4.5 ja 4.6 on esitetty.

\section{PAKKOAVIOLIITON ERILLISKRIMINALISOINNIN ARVIOINTIA}

Kriminalisoinnilla inhimilliseen tekoon liitetään rangaistusuhka, ja näin pyritään vaikuttamaan henkilöiden käyttäytymiseen. Tavoitteena on suojella jotakin tiettyä oikeushyvää. Dan Fränden mukaan Suomessa demokraattisena ja moniarvoisena yhteiskuntana suojeltavien arvojen tulee liittyä yksilön itsemääräämisoikeuden ja vapauspiirin toteuttamiseen. Usein nämä suojeltavat arvot sisältyvät jollain lailla perus- ja ihmisoikeuksiin. ${ }^{\mathbf{5 6}}$ Fränden näkemykseen nojaten voidaan argumentoida, että yksilön vapaus valita itse kumppaninsa on suojeltavien arvojen ydinalueella ja että pakkoavioliiton kriminalisointi on siten aiheellista. Tätä johtopäätöstä tukee myös se, että pakkoavioliitto on jo ennestään rangaistavissa muiden rikosnimikkeiden alla.

Onko mahdollisuus rangaista muiden kriminalisointien nojalla kuitenkaan riittävää? Monien tahojen mukaan ei. Kevät Nousiainen ja Merja Pentikäinen tarkastelivat vuonna 2013 kriittisesti Istanbulin sopimuksen ratifiointia Suomessa. He katsovat sopimuksen yhdistävän ihmisoikeudet ja rikosoikeudelliset kysymykset ja asettavan valtioille useita selviä velvoitteita. Kuitenkaan kansallisiin muutostarpeisiin ei ole heidän arvionsa mukaan riittävästi perehdytty ratifiointia koskevassa mietinnössä, vaan mietintö on ymmärrettävissä jopa niin, ettei Suomen tarvitsisi tehdä merkittäviä muutoksia sopimusvelvoitteidensa täyttämiseksi. ${ }^{57}$ Kuten artikkelin 4.4 luvussa on esitetty, naisiin kohdistuvan väkivallan ja perheväkivallan ehkäisemisestä ja torjumisesta tehdyn Euroopan neuvoston yleissopimuksen voimaansaattamista valmistelleen työryhmän mietinnössä pakkoavioliitonkin on katsottu kuuluvan ihmiskauppalainsäädännön soveltamisalaan ja erilliskriminalisoinnin olevan siten tarpeeton. Mahdollinen tarve lainsäädännön

54 Explanatory report CETS 210, s. 38.

55 TyVM $15 / 2014 \mathrm{vp}$

56 Frände 2005, s. 21-23.

57 Nousiainen \& Pentikäinen 2013 , s. 456 tarkemmalle arvioimiselle nousi kuitenkin esiin. ${ }^{\mathbf{5 8}}$ Tämä tarve realisoitui vuosia myöhemmin, ja muutostarpeiden arviointi on oikeusministeriössä tätä artikkelia kirjoitettaessa parhaillaan käynnissä. ${ }^{59}$ Seuraavaksi onkin syytä punnita mahdollisen erilliskriminalisoinnin hyötyjä ja haittoja. Arvioinnin taustaoletuksena on, että rikos olisi virallisen syytteen alainen, eikä asianomistajarikos kuten edellä esitelty pakottaminen.

\section{I Rikosoikeuden funktioista}

Yleisestävyys on nähty rikoslain tärkeäksi funktioksi. Rikoslaki erittelee moitittavan käyttäytymisen ja siten ihmisten odotetaan pidättäytyvän siitä. Rangaistuksen uhalla pyritään estämään tietynlaista käytöstäja toisaalta kannustamaan toista. ${ }^{60}$ Jotta yleisestävyys toteutuisi, tulisi rangaistavan teon kuitenkin käydä riittävän selvästi ilmi laista: ihmisen ei yleisestävyyden valossa voida odottaa pidättäytyvän teosta, jonka tämä ei tiedä olevan kielletty. Nousiainen ja Pentikäinen peräänkuuluttavat tämän funktion soveltamista myös Istanbulin sopimuksessa määriteltyyn naisiin kohdistuvaan väkivaltaan nähden. Mikäli siis yleisestävyyteen ollaan valmiita vetoamaan, tulee myös naisiin kohdistuva väkivalta saattaa yleisestävyyden piiriin tuomitsemalla teot rikoslaissa. ${ }^{61}$ Tekojen piilottaminen toisten rikosnimikkeiden taakse hallituksen esityksiin ei edesauta yleisestävyyden toteutumista. Pakkoavioliiton kriminalisoinnilla olisi myös symbolinen painoarvo. Kyseessä on ihmisoikeusloukkaus, joka on täysin Suomen oikeusjärjestelmän arvojen vastainen. Erillisellä rikosnimikkeellä Suomi lähettäisi selvän viestin, ettei se hyväksy avioliittoon pakottamista missään olosuhteissa.

Suomessa rikosoikeutta on vanhastaan pidetty myös moraalin luojana: sillä pyritään yhtäältä vahvistamaan yhteiskunnan hyvänä pitämiä tapanormeja ja toisaalta syventämään mielikuvia epätoivottavien tekojen moraalittomuudesta. Näin ollen yksilö sisäistäisi yhteisön rikoslakiin kirjaaman normin osaksi omaa moraalikäsitystään. Tapani ja Tolvanen tuovat edellä esitetyn lisäksi esiin ajatuksen siitä, että demokraattisessa yhteiskunnassa rikoslaki vastaa yleensä tietyin määrin myös kansalaisten käsitystä oikeasta ja väärästä. Tätä tukee perusoikeuksiin sidottu ja monet näkemykset huomioon ottava lainsäädäntöprosessi. Tämän seurauksena kansalaiset suhtautuvat lähtökohtaisesti myönteisesti lakiin, joka on demokraattisesti säädetty. ${ }^{62}$ Moraalin luomista pohdittaessa tulee kuitenkin ottaa huomioon, että pakkoavioliitto vaikuttaa Suomessa olevan pääosin maahanmuuttajiin kohdistuva ilmiö. Relevanteilla ihmisryhmillä on usein tausta toisenlaisissa oikeuskulttuureissa, joissa muun muassa uskonto ja perinteet voivat näytellä demokraattista päätöksentekoa suurempaa roolia. Niinpä voidaan kysyä, missä määrin lähtökohtaisesti ulkopuolelta tuleva moraaliohje vaikuttaa ihmisten sisäiseen moraaliin. Toisaalta

58 Naisiin kohdistuvan väkivallan ja perheväkivallan ehkäisemisestä ja torjumisesta tehdyn Euroopan neuvoston yleissopimuksen voimaansaattamista valmistelleen työryhmän mietintö 28.3.2013, s. 65-66. 59 Ihmisoikeusliitto ry 5.4.2018.

59 Ihmisoikeusliitto ry 5.4.2018.

61 Nousianen \& Pentikäinen 2013, s. 457.

62 Tapani \& Tolvanen 2013, s. 46-47. 
Suomessa kasvaviin nuoriin ja lapsiin kansallisella oikeusjärjestelmällä saattaa olla suurempi vaikutus kuin heidän vanhempiinsa. Tämä on merkityksellistä, sillä juuri lapset ja nuoret ovat suurimmassa riskissä joutua pakotetuiksi avioliittoon

Suomalainen rikosoikeus on lähtökohdiltaan tekorikosoikeutta. ${ }^{63}$ Yksittäisen teon tulee siis lähtökohtaisesti täyttää laissa asetetut edellytykset ollakseen rangaistava. Oksasen mukaan naisten itsemääräämisoikeuteen puuttuvat rikokset ovat kuitenkin usein prosesseja, jotka eivät sovi tekorikosoikeuden rajattuun kehikkoon. ${ }^{64}$ Saman kannan jakaa Hong, jonka mukaan nykyään tekorikosoikeudellisessa ajattelussa on kuitenkin alettu ottaa tekojen konteksti yhä paremmin huomioon. Tästä toimii esimerkkinä muuttunut lainsäädäntö vainoamista ja seksuaalista ahdistelua koskien. Hong on kuitenkin tyytymätön siihen, ettei suomalainen rikosoikeus edelleenkään riittävästi huomioi yhteisöllisyyden aiheuttamia rajoituksia yksilön toimintaan. Yhteisöllisessä kulttuurissa esiintyy individualistisesta kulttuurista poiketen useita sisäisiä käytäntöjä, jotka estävät naista hakemasta apua viranomaisilta. ${ }^{\mathbf{6 5}}$ Erilliskriminalisoinnilla voitaisiin kenties ottaa teon yhteisöllinen konteksti paremmin huomioon kuin mikä on mahdollista monenlaisia tekoja kattavissa yleisemmissä säännöksissä.

Ongelmalliseksi muodostuu kuitenkin rikosoikeuden kriminalisointiperiaatteisiin kuuluva ultima ratio -periaate, jonka mukaisesti rikoslain tulee olla viimeinen käytettävä keino. Muut suojaa tarjoavat järjestelyt saavat etusijan suhteessa siihen ja rikosoikeuden käyttö tulee rajoittaa pienimpään perusteltavissa olevaan minimiin. ${ }^{66}$ Kriminalisointiin ei tulisi turvautua ennen kuin muut yhteiskunnan keinot ongelman ratkaisemiseksi osoittautuvat tehottomiksi. Tapani ja Tolvanen korostavat tätä velvollisuutta todeten, ettei kriminalisointiin saa turvautua vain varmuuden vuoksi, mikäli muiden yhteiskuntapoliittisten keinojen tehokkuudesta on vain puutteellista tietoa. Ultima ration ulkoisella tasolla rikosoikeutta tarkastellaan suhteessa muuhun oikeusjärjestykseen, kuten sosiaalipolitiikan keinoihin. Sisäisellä tasolla tarkastellaan rikosoikeudelliseen järjestelmään itseensä lukeutuvia kriminalisointeja ja niiden suhdetta toisiinsa. Näin ollen kriminalisointia ei pidetä periaatteen mukaisena, mikäli jo olemassa olevat rikossäännökset kattavat kyseessä olevan menettelyn. ${ }^{67}$ Sekä Ihmisoikeusliiton että Kriminologian ja oikeuspolitiikan instituutin selvitysten perusteella on kiistatonta, ettei muiden yhteiskuntapoliittisten keinojen tehottomuudesta ole varmaa tietoa. Selvityksistä käy ilmi, että viranomaisilla ja muilla ammattilaisilla on puutteelliset tiedot ja ohjeet pakkoavioliitoista

63 Ks. aiheesta esim. Tapani \& Tolvanen 2013, s. 177.

64 Oksanen 2012, s. 619.

65 Hong 2017, s. 371

66 Lappi-Seppälä 2008, Rangaistus kriminaalipolitiikan keinona; Kriminalisointiperiaatteet.

67 Tapani \& Tolvanen 2013, s. 91 sekä niihin puuttumisesta. Tämä koskee muun muassa terveydenhoito- ja opetustyötä. ${ }^{68}$ Näin ollen ultima ration ulkoisella tasolla kriminalisoinnin edellytykset eivät täyty, sillä pakkoavioliittojen estäminen saattaisi toteutua myös muita yhteiskuntapoliittisia keinoja kehittämällä. Tämä tarkastelu on kuitenkin sikäli turha, että Istanbulin sopimus yksiselitteisesti vaatii pakkoavioliittojen säätämistä rangaistavaksi, ja Suomi on sitoutunut tähän. Sisäisellä tasolla taas voidaan vedota samoihin perusteisiin, kuin millä kriminalisointivelvoite sivuutettiin hallituksen esityksessä Istanbulin sopimuksen voimaan saattamiseksi (HE 155/2014 vp): jo olemassa olevien ihmiskaupan ja pakottamisen kieltävien säännösten voidaan katsoa kattavan myös avioliittoon pakottamisen.

Kuitenkin sekä Dan Frände että Sakari Melander toteavat, ettei lainsäätäjä aina ota ultima ratio -periaatetta vakavasti, vaan rikosoikeudellinen rangaistusseuraamus saatetaan ottaa käyttöön kevyemminkin perustein. Vaikka rikoslain viimesijaisuus tulee olla tavoitteena, on kriminalisoinnin arvioinnissa otettava huomioon sääntelyn suojeluintressin painavuus. ${ }^{69}$ Tässä tapauksessa kyseessä on teko, joka on katsottu rikosoikeuden alaan kuuluvaksi, eli edellä mainittua ultima ration ulkoista tasoa ei tarvitse pohtia. Sen sijaan sisäisen tason ongelmallisuutta voidaan verrata sekä järjestäytyneen rasismin kieltämisestä että inmiskauppasääntelyn lisäämisestä rikoslakiin käytyyn keskusteluun. Melander kirjoittaa näistä Perustuslakiblogissa todeten, että rasistisia ryhmiä koskevan sääntelyn piilottaminen järjestäytyneen rikollisryhmän toimintaan osallistumista koskevan sääntelyn alle ei ole perusteltua ottaen huomioon Suomelle asetettu selkeä kriminalisointivelvoite ja toisaalta sääntelyn ennustettavuus. Sääntelyn selkeys rikosnimikkeet mukaan lukien lisäisi ennakoitavuutta ja myös sääntelyn preventiivistä tehoa. ${ }^{\mathbf{7 0}}$ Näin historia toistaa itseään, sillä olosuhteet ovat verrattavissa pakkoavioliittoa koskevaan sääntelyyn; rikoslaki periaatteessa kattaa teon, mutta omaa rikosnimikettä ei ole luotu vaan sääntely on epäselvää.

Tärkeänä erilliskriminalisoinnin puolestapuhujana voidaan pitää Suomen perustuslain 2 luvun 8 §:ässä säädettyä rikosoikeuden laillisuusperiaatetta, jota on käsitelty jo luvussa 4.5 inmiskauppalainsäädännön soveltuvuutta arvioitaessa. Nykytilanteessa ongelmallisiksi muodostuvat laillisuusperiaatteen sisältämät epätäsmällisyys- ja analogiakielto. Nykyisen sääntelyn epätäsmällisyys on ongelma, joka haittaa ennakoitavuuden toteutumista. Fränden mukaan analogiakieltoon sisältyy oletus, että sekä lain esityöt että KKO:n oikeuskäytäntö pysyvät

68 Ks. Hansen ym. 2016, s. 89-90 ja Toivonen 2017, s. 11. Ihmisoikeusliiton selvityksessä todetaankin, ette pakkoavioliittojen tunnistamiseen ja uhrien auttamiseen ole riittävästi toimintamalleja. Viranomaisten kouluttaminen ja ohjeistus sekö maahanmuuttajayhteisöissä tehtävä asennemuutostyö olisivat myös tarpeellisia toimia.

69 Frände 2005, s. 25 ja Melander 18.9.2016.

70 Melander 18.9.2016. 
lain sanamuodon rajoissa. ${ }^{71}$ Kuten edellä on todettu, ei lain sanamuoto ihmiskaupparikoksissa ole niin selvä, että sen perusteella olisi mahdollista ennakoida, mikä on rangaistavaa käytöstä. Periaatteen mukaista olisikin säätää uusi täsmällinen rikosnimike, eikä hallituksen esitysten välityksellä keinotekoisesti laajentaa inmiskauppalainsäädännön soveltamisalaa.

\subsection{Lisää tehokkuutta vai tehottomuutta?}

Pakkoavioliittoa koskeva lainsäädäntö on tällä hetkellä monitulkintaista ja haastavaa, mikä Ihmisoikeusliiton haastattelemien ammattilaisten mukaan hankaloittaa ilmiöön

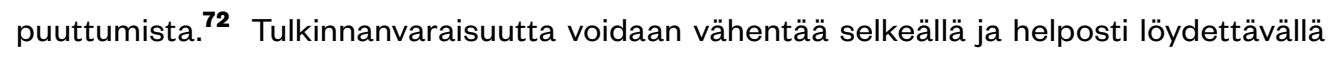
lainsäädännöllä. Tällä hetkellä avioliittoon pakottamisen rangaistavuuden selvittämiseksi uhrin tulisi osata etsiä tietoa lain esitöistä asti, mikä ei ole realistinen odotus edes kantaväestölle. Lisäksi maahanmuuttajien kannalta ongelmalliseksi muodostuu sekä kielimuuri että koko oikeusjärjestelmän vieraus. Sosiaali- ja terveysministeriön oppaassa "Maahanmuuttajanaiset ja väkivalta" vuodelta 2005 korostetaankin kieli- ja kansalaistaidon puutetta esteenä avun hakemiselle. Naisilla ei välttämättä ole riittävää tietoa oikeuksistaan eikä tarjolla olevista palveluista. ${ }^{73}$ Myös poliisiammattikorkeakoulun selvityksen mukaan maahanmuuttajanaiset ovat erityisen heikossa asemassa yhteiskunnassa johtuen muun muassa kielivaikeuksista, rasismista ja kulttuurisista uskomuksista. Myös täydellinen riippuvuus miehestä voi vaikeuttaa avun hakemista väkivaltatilanteissa. ${ }^{\mathbf{7 4}}$ Selvityksessä esitetty soveltunee myös tilanteisiin, joissa nainen on riippuvainen lähisuvusta, kuten vanhemmista tai miespuolisista sukulaisista. Tietoisuus omasta oikeudesta päättää avioliitosta voi olla edellä esitettyjen kielivaikeuksien ja kulttuuristen uskomusten johdosta puutteellinen. Vaikka lain soveltaminen on aina tulkintaa, voisi erilliskriminalisointi helpottaa tätä tehtävää niin uhrin, tekijän kuin viranomaisenkin näkökulmasta.

Pakkoavioliittojen esiintyminen Suomessa, mutta näkymättömyys rikosprosessissa indikoivat, etteivät nykyiset rangaistussäännökset tai niiden soveltamiskäytäntö todellisuudessa sovellu kovinkaan hyvin pakkoavioliittotapauksiin. Lausunnossaan työvaliokunnalle yhteenvedosta Istanbulin sopimuksen toimeenpano-ohjelmaan esitetyistä toimenpiteistä Monika-Naiset liitto ry esitti huolensa toimenpiteiden riittämättömyydestä varmistamaan pakkoavioliiton rangaistavuus ja vaati erilliskriminalisointia. ${ }^{75}$ Oikeusministeriön mukaan tuomioistuimissa tai esitutkinnassa käsiteltävissä ihmiskauppaa, törkeää ihmiskauppaa tai pakottamista koskevissa tapauksissa ei ole lähes koskaan kyseessä avioliittoon pakottaminen. ${ }^{76}$ Toivonen on käyttänyt

71 Frände 2005, s. 56.

72 Hansen ym. 2016, s. 90.

73 Kyllönen-Saarnio \& Nurmi 2005, s. 46-47.

74 Korhonen \& Ellonen 2007, s. 21.

75 Monika-Naiset liitto ry 26.10.2017.

76 Oikeusministeriö 18.10.2017. selvityksessään lähteinä poliisi- ja tuomioistuintilastoja, joista selviää ihmiskauppatapausten olevan lähinnä työ- tai prostituutioperäisiä ja pakottamisen liittyvän vain harvoin parisuhdetai avioliittoasioihin ylipäänsä. Myöskin syyteharkinnassa avioliittoon pakottamista esiintyy vain täysin satunnaisesti, ja nämäkin tapaukset ovat usein vain eriasteisia epäilyjä. ${ }^{\mathbf{7 7}}$ Näin ollen rikosoikeudellinen puuttuminen tapauksiin ei ole oikeassa suhteessa ilmiön laajuuteen. Sama koskee Venla Rothin väitöstutkimuksen mukaan koko ihmiskauppasääntelyä. Ihmiskauppa on määritelty laajasti ja monitulkintaisesti, mutta sääntelyn soveltaminen ja tulkinta on toisaalta suppeaa, minkä johdosta suurin osa ihmiskaupan uhreista jää Suomessa tunnistamatta. ${ }^{78}$ Ihmiskauppasääntelyn riittävyyttä arvioitaessa voidaan kärjistäen jopa väittää pakkoavioliiton olevan näkymätön osa-alue laajempaa piilorikollisuutta.

Sääntelyn soveltamisongelmat eivät myöskään liity ainoastaan poliisiin tai tuomioistuimiin vaan alkavat jo ns. ruohonjuuritasolta. Ihmisoikeusliiton haastattelemat eri alojen ammattilaiset kokevat epävarmuutta ottaa pakkoavioliitto puheeksi asiakkaiden kanssa. Osa myös kokee, ettei se kuulu heidän tehtäviinsä. Kuitenkin tehokas ilmiöön puuttuminen vaatii useiden viranomaistahojen yhteistyötä. ${ }^{\mathbf{9}}$ Ammattilaisten aktiivista puuttumista voisi lisätä, mikäli avioliittoon pakottaminen olisi nimenomaisesti säädetty rangaistavaksi rikoslaissa. Tällöin asiantilan aktiivisempi selvittäminen voitaisiin kokea enemmän ihmisoikeusloukkauksen estämisenä kuin toisten henkilökohtaiseen perhe-elämään puuttumisena.

Pakkoavioliittotapauksissa uhrilla on usein korkea kynnys nostaa syyte läheisiään vastaan Useat uhrit eivät toivo rikosprosessia, vaan esimerkiksi vain avioeroa tai puolison oleskeluluvan epäämistä. ${ }^{\mathbf{8 0}}$ Rikosprosessin esteenä onkin painostuksen ja uhkien kollektiivisuusja moninaisuus. On mahdollista, että uhrin koko lähiyhteisö hylkäisi uhrin, jos tämä nostaisi syytteen. Osa Toivosen haastattelemista ammattilaisista kokeekin, ettei rikosprosessiin vaikuta olevan edes mahdollisuutta, ellei tapaukseen liity fyysistä väkivaltaa. ${ }^{\mathbf{8 1}}$ Yhteisölliseen väkivaltaan liittyy Hongin mukaan kahdella tasolla ilmenevää kontrollointia. Yhteisöllisessä kontekstissa kasvaneet yksilöt ovat sisäistäneet ryhmänsä arvot ja vaatimukset hyväksyttävän käytöksen perustaksi. Siten he arvioivat ja laskelmoivat, millaisia seurauksia yhteisön kieltämistä teoista voisi pahimmillaan tulla. Näin ollen yhteisön kontrollin lisäksi ilmenee myös itsekontrollia, ja nämä molemmat rajoittavat yksilön toimintamahdollisuuksia. ${ }^{\mathbf{8 2}}$ Tällöin virallisen syytteen alaisuus toisi tekijät varmemmin oikeuden eteen kuin syytteen riippuminen asianomistajasta. Tämä taas on tilanne silloin, jos teko katsotaan rikoslain 25 luvun 8 §:n mukaiseksi pakottamiseksi.

77 Toivonen 2017, s. 12

78 Roth 2012, s. 289. Uhrien heikko tunnistaminen liittyy tutkimuksen mukaan myös auttamisjärjestelmän ehdollisuuteen ja kytkökseen rikosprosessin etenemiseen.

79 Hansen ym. 2016, s. 88

80 Toivonen 2017, s. 11

81 Toivonen 2017, s. 9.

82 Hong 2017, s. 367-368. 
Toisaalta näyttökysymysten vaikeus saattaisi tehdä kriminalisoinnista kuolleen kirjaimen. Liisa Nieminen toteaa yksittäistapauksessa olevan vaikeaa selvittää, onko kyse ollut pakkoavioliittoon vihkimisestä. $^{\mathbf{8 3}}$ Ero järjestetyn avioliiton ja pakkoavioliiton välillä voi olla vaikea näyttää toteen etenkin tilanteissa, joissa esiintynyt pakottaminen on ollut hienovaraista. Ero voi Tuulikki Mikkolan mukaan hämärtyä myös avioliiton osapuolten silmissä, sillä painostus suvun osalta voi olla voimakasta. Tällöin suvun järjestämän avioliiton vastustaminen ei välttämättä yksilön silmissä näyttäydy aitona mahdollisuutena ${ }^{\mathbf{8 4}}$ Sana vastaan sanaa -tilanteissa voimakkaan suostuttelun ja pakottamisen välistä rajaa voi olla mahdoton näyttää toteen. Kuolleena kirjaimena säännös ei hyödytä ketään vaan pikemminkin köyhdyttää rikoslain auktoriteettia.

Erilliskriminalisoinnin potentiaaliseen tehottomuuteen liittyy myös mahdollisuus siitä, että poliisin ja syyttäjän lisäksiilmiöjäisientisestään piiloon myös muilta toimijoilta. Poliisiammattikorkeakoulun selvityksessä vuodelta 2007 kartoitetaan poliisin tietoon tullutta maahanmuuttajanaisiin kohdistuvaa väkivaltaa. Tarkastelussa ovat niin fyysinen kuin seksuaalinenkin väkivalta sekä väkivallalla uhkaaminen. Selvityksen mukaan maahanmuuttajanaiset eivät vaatineet tekijälle rangaistusta suurimmassa osassa parisuhdeväkivaltatapauksista. Mikäli nainen kuitenkin vaati rangaistusta, perui hän yleensä vaatimuksen muutaman päivän kuluessa ja toivoi käsittelyn keskeyttämistä. Näin ollen poliisi haluttiin lähinnä rauhoittamaan akuutti tilanne. ${ }^{85}$ Tämä ilmiö on samansuuntainen kuin edellä esitetty Toivosen selvityksen tulos, jonka mukaan pakkoavioliiton uhrit eivät useinkaan halua läheisiään rikosprosessiin. ${ }^{\mathbf{8 6}}$ Näin ollen erilliskriminalisointi ja virallisen syytteen alaisuus saattaisi viedä ilmiön vielä entistä enemmän piiloon. Uhrit eivät välttämättä uskaltaisi hakea itselleen apua edes sosiaaliviranomaisilta siinä pelossa, että tieto asiasta kulkeutuu syyttäjälle ja läheiset voivat joutua rangaistusvastuuseen.

\subsection{Yksilön ja kulttuurin kunnioittamisen problematiikka}

Mikäli syyttäjälle annettaisiin kriminalisoinnilla oikeus nostaa syyte asianomistajasta riippumatta, voitaisiin tämän katsoa rajoittavan uhrin itsemääräämisoikeutta. Monien filosofien ja oikeusteoreetikkojen mukaan valtion olemassaolon edellytys on valtion väkivaltakoneisto. ${ }^{87}$ Hallinnolla ja viranomaisilla tulee olla legitiimi oikeus käyttää väkivaltaa ja toisaalta kieltää sen käyttö muilta. Rikoksentekijän katsotaan oikeudenloukkauksella aiheuttaneen itsensä ja yhteiskunnan välille konfliktin, joka sovitetaan rangaistuksella ${ }^{\mathbf{8 8}}$. Tämän voidaan katsoa etäännyttävän uhri omista oikeuksistaan - loukkausta ei enää nähdäkään häneen, vaan yhteiskuntaan kohdistuvana. Mikäli edellä esitettyjen selvitysten katsotaan edustavan uhrien

83 Nieminen 2013, s. 157.

84 Mikkola 2013, s. 857.

85 Korhonen \& Ellonen 2007 , s. 53

86 Toivonen 2017, s. 11

87 Ks. Esim. Weber, Max: Politics as a Vocation 1919 tai Hobbes, Thomas: Leviathan 165

88 Tapani \& Tolvanen 2013, s. 53 aitoa ja vapaaehtoista kantaa siitä, etteivät he halua pakottamiseen osallistuneita läheisiään rangaistavan, voisi virallisen syytteen alaisuus loukata uhrin oikeuksia toistamiseen. Uhrin omaa tahtotilaa ei tällöin kunnioitettaisi. Ihmisoikeusliiton maahanmuuttajien parissa tekemän työn yhteydessä on käynyt ilmi, että yhteisöllisemmissä kulttuureissa myös avioliittoon liittyviä ongelmia ratkotaan yhteisöllisesti eikä luottamus poliisiin tai viranomaisiin välttämättä ole korkealla ${ }^{89}$. Oikeusvaltion toimivuuden kannalta yksilön tai yhteisön käsiin jätetty oikeus näyttäytyisi kuitenkin hyvin ongelmallisena. Lisäksi Istanbulin sopimuksen 55 artikla nimenomaisesti kieltää jättämästä syytteeseenpanoa yksinomaan uhrien toimien varaan.

Kriminalisointi voi toisaalta leimata etnisiä vähemmistöjä, sillä kyseessä on vahvasti kulttuurisidonnainen ilmiö. Tämä vaikuttaisi negatiivisesti jo valmiiksi kantaväestöön nähden huonommassa asemassa oleviin ihmisryhmiin. ${ }^{\mathbf{9 0}}$ Irakin Naisten Yhdistyksen varapuheenjohtaja Ala Saeedin mukaan kulttuurikäsitykset riippuvat perheestä, eikä esimerkiksi arabikulttuuri ole yksi yhtenäinen konsepti. Hän myös kokee, etteivät viranomaiset suhtaudu yhtä vakavast maahanmuuttajaperheiden asioihin kuin kantasuomalaisten..$^{91} \mathrm{hm}$ isoikeusliiton selvityksessä ilmaistaan myös huoli siitä, että puhe kunniaan liittyvästä väkivallasta ylipäätään voi korostaa oletusta siitä, ettei sukupuolten välinen tasa-arvo koskaan toteudu maahanmuuttajataustaisissa perheissä. ${ }^{\mathbf{2 2}}$ Pakkoavioliiton kriminalisointia koskevaan keskusteluun liittynee riski tiettyjen kulttuurien leimaamisesta. Toisaalta on kuitenkin otettava huomioon Istanbulin sopimuksen 4(3) artiklan syrjinnän kielto: toimet uhrien oikeuksien suojelemiseksi on varmistettava syrjimättä ketään mm. maahanmuuttajataustan tai alkuperän perusteella. Näin ollen leimaamisen pelkoa suurempi pelko tulisi kenties olla vähemmistöihin kuuluvien naisten ja tyttöjen oikeuksien heikompi toteutuminen kantaväestöön verrattuna.

Suomen perustuslain 2 luvun 11 §:ssä on turvattu uskonnon ja omantunnon vapaus ja 17 §:ssä ryhmien oikeus ylläpitää ja kehittää omaa kulttuuriaan. On kiistatonta, että järjestetyt avioliitot kuuluvat olennaisena ja hyväksyttävänä osana moneen kulttuuriin. Erojärjestetyn ja pakotetun välillä onkin tärkeää pitää selvänä kriminalisointikeskustelussa. Keskustelua pidemmälle vietäessä voidaan jopa argumentoida inmisoikeuksien taustan olevan länsimaisessa, individualistisessa kulttuurissa, minkä johdosta ne eivät ota riittävästi huomioon yhteisöllisiä seikkoja. Perustuslakia uudistettaessa lainsäätäjä kuitenkin linjasi, ettei uskonnon ja omantunnonvapauteen vedoten voida oikeuttaa toimia, jotka loukkaavat inmisarvoa tai muita perusoikeuksia tai ovat oikeusjärjestyksen perusteiden vastaisia. Hallituksen esityksessä käytettiin esimerkkinä tästä moniavioisuutta. ${ }^{93}$ Perustuslain esitöiden lisäksi myös Istanbulin sopimuksessa asetetaan samankaltainen linjaus. Artiklan 42 mukaan kulttuurin, tavan, uskonnon,

89 Hansen ym. 2016, s. 87

90 Toivonen 2017, s. 15.

91 Helander 23.3.2018

92 Hansen ym. 2016, s. 1 ja 36

93 HE 309/1993 vp s. 56 
perinteen tai niin sanotun "kunnian" ei voida rikosoikeudenkäynnissä katsoa oikeuttavan yleissopimuksen soveltamisalaan kuuluvia väkivallantekoja.

Edellä esitetylle on saatavissa tukea myös oikeuskäytännöstä. Korkein hallinto-oikeus on oleskelulupaa ja lapsena solmittua avioliittoa käsittelevässä ratkaisussaan KHO 2005:87 korostanut yksilön oikeutta avioliittoon suhteessa yhteisön oikeuksiin. Korkein hallintooikeus lausui seuraavaa: "Myös maahanmuuttajatytöillä on kulttuuritaustasta ja uskonnosta riippumatta oikeus täyttä ja vapaaehtoista suostumusta ilmentävään aviopuolison valintaan". Tapauksessa uhrin kulttuuritaustalla ei voitu oikeuden mukaan puolustaa sitä, että hänet oli viety lapsena kolmanteen maahan ja siellä naitettu serkulleen, jota hän ei ollut tavannut varhaislapsuuden jälkeen. ${ }^{94}$ Tapauksessa oikeudellisen punninnan pääpaino on lapsen etua koskevissa kysymyksissä. Kuitenkin ennakkoratkaisun viesti myös yksilön ja yhteisön oikeuksien punninnan välillä on selvä: yksilön oikeus valita puolisonsa on vahvempi kuin kulttuurin ja uskonnon vastakkaiset arvot.

\section{JOHTOPÄÄTÖKSIÄ}

Ei pitäisi olla mahdollista, että Suomessa tulee vuosittain ilmi kymmenittäin kriminalisointivaateen alaisia ihmisoikeusloukkauksia siten, että ne pysyvät kuitenkin rikosoikeuden ulottumattomissa. Istanbulin sopimuksen kansallisessa voimaansaattamisessa lainsäätäjän lähtökohtana oli senhetkisen lainsäädännön riittävyys pakkoavioliiton kriminalisoimiseksi. Työryhmän mietintö kirvoitti kuitenkin eriäviä mielipiteitä, joissa kritisoitiin mietinnön laatua, yleispiirteisiä lausumia sekä ylimalkaisuutta ${ }^{95}$. Lisäksi edellä käsiteltyjen Ihmisoikeusliiton ja Kriminologian ja oikeuspolitiikan instituutin tekemien selvitysten perusteella on ilmeistä, ettei pakkoavioliittoon puuttuminen ole käytännössä Suomessa tehokasta. Pakottamissääntelyn soveltumisen ongelmana on se, että kyseessä on asianomistajarikos, joka ei ota huomioon uhrin riippuvuussuhdetta tekijöistä ja siten tämän haavoittuvaista asemaa. Ihmiskauppasääntelyn soveltamisongelmat taas kulminoituvat sen epäselvyyteen ja tulkintavaikeuksiin ${ }^{\mathbf{9 6}}$.

Olisiko avioliittoon pakottamisen erilliskriminalisointi näin ollen aiheellista? Periaatetasolla suurin punninta tapahtuu edellä esitettyjen ultima ratio -periaatteen ja laillisuusperiaatteen välillä. Rikoslakiin ei tulisi lisätä uusia kieltoja, jos teko on jo entuudestaan sääntelyn piirissä,

94 KHO 2005:87.

95 Naisiin kohdistuvan väkivallan ja perheväkivallan ehkäisemisestä ja torjumisesta tehdyn Euroopan neuvoston yleissopimuksen voimaansaattamista valmistelleen työryhmän mietintö 28.3.2013. Mietinnön liitteenä löytyvät Vähemmistövaltuutetun eriävä mielipide, Monika-Naiset liitto ry:n eriävä mielipide ja Amnesty International Suomen osasto ry:n eriävä mielipide.

96 Ks. lisäksi Roth 2012, s. 288. Roth argumentoi, että oikeudelliset rakenteet ja käytännöt aiheuttavat sen, että ihmiskauppalainsäädäntö ylipäätään on epäsuorasti naisia syrjivä. mutta toisaalta sääntelyn pitäisi olla riittävän täsmällistä ja ennakoitavaa. Istanbulin sopimuksen asettama kriminalisointivelvoite on niin selkeä, ettei Suomen lainsäädäntö soveltamisvaikeuksineen tee sille oikeutta. Rangaistavuus periaatteessa on eri asia kuin rangaistavuus käytännössä.

Melander nimeää laillisuusperiaatteen rikosoikeuden tärkeimmäksi periaatteeksi ja täsmällisyys on kiistatta sen keskeinen osatekijä. Hän esittää laillisuusperiaatteen ytimeksi muodostuneen perustuslakivaliokunnan käytännössä sen, että rikoksen tunnusmerkistön on oltava riittävän täsmällinen siten, että teon tai laiminlyönnin rangaistavuus on ennakoitavissa sanamuodon perusteella. ${ }^{97}$ Lainsäädännön sisältö ihmisoikeusloukkauksen suhteen ei saisi olla epäselvä. Ottaen huomioon nämä seikat sekä sen, ettei avioliittoon pakottamisen rikosoikeudellisen rangaistavuuden tarpeellisuutta itsessään ole kyseenalaistettu, voitaisiin erilliskriminalisoinnin katsoa lähinnä selkeyttävän oikeustilaa ja olevan siten perusteltua ja laillisuusperiaatteen mukaista.

Käytännön tasolla erilliskriminalisointi voisi helpottaa ilmiöön puuttumista, sillä selkeä lainsäädäntö poistaisi tulkinnallista epävarmuutta. Toisaalta edellä on esitetty riski ilmiön menemisestä entisestään piiloon sekä mahdolliset näyttövaikeudet. Luonnollisesti teon nimeäminen rikokseksi voi saattaa sen entisestään piiloon, sillä yhteiskunta suhtautuu siihen tällöin selvän kielteisesti. Kuitenkin avioliittoon pakottaminen on tällä hetkellä lähes näkymätön ilmiö rikosprosessissa Suomessa, joten sillä saralla ei voida väittää olevan paljon hävittävää. Toki tämäkin mahdollisuus tulee ottaa huomioon lainsäädäntöä ja viranomaisten toimintaa suunniteltaessa. Näyttökysymyksiin liittyvät vaikeudet on myös nostettu tarkastelussa esiin. Ei ole tarkoituksenmukaista säätää rikoslakiin "kuollutta kirjainta", mutta samat näyttövaikeudet ovat nyt jo olemassa, kun sääntely on piilotettu toisten rikosnimikkeiden ja hallitusten esitysten taakse. Toisaalta teon kontekstuaalisuus ja erityispiirteet saattaisi olla mahdollista ottaa erilliskriminalisoinnissa paremmin huomioon, kuin mikä on mahdollista useita tekotyyppejä kattavissa säädöksissä. Näin voitaisiin myös välttää tiettyjen tekomuotojen tippuminen pois virallisen syytteen alaisuudesta.

Pakkoavioliittoa nimenomaisesti koskevalla rangaistussäännöksellä voitaisiin mahdollisesti myös välittää sekä uhrille että tekijälle voimakkaampi viesti siitä, ettei teko ole hyväksyttävä. Näin rikosoikeuden yleisestävyys ja ennakoitavuus voisivat paremmin toteutua. Keskustelussa ja tapauksiin puuttumisessa on kuitenkin tärkeää muistaa yksilön ja yhteisön oikeuksien kunnioittaminen. Näihin seikkoihin liittyvät mahdolliset ongelmat tuskin koituisivat kuitenkaan kompastuskiviksi ottaen huomioon päämäärän merkittävyys - ihmisoikeuksien ja Suomen kansainvälisten velvoitteiden menestyksekkäämpi toteuttaminen.

97 Melander 2015, s. 646 
Kriminalisointi itsessään ei kuitenkaan riitä estämään pakkoavioliittoja, vaan monisyiseen ilmiöön puuttuminen vaatii monenlaisia toimenpiteitä. Ihmisoikeusliiton haastatteluissa kannatusta saikin palvelupainotteisuus suhteessa rangaistuslähtöiseen lähestymiseen. ${ }^{\mathbf{9 8}} \mathrm{Niin}$ kauan, kun uhrien tukipalvelut eivät ole kunnossa, on rikosoikeudellisen rangaistavuuden hyöty tekijästä riippuvaiselle uhrille vähäinen. Esimerkiksi turvakotien suhteen tilanne Suomessa on heikko: Ensi- ja turvakotien liiton yhdistysten mukaan turvakotipaikkoja on riittänyt vain noin puolelle hakijoista. ${ }^{99}$ Näin ollen pakkoavioliittoihin puuttumista tulee Suomessa kehittää kokonaisvaltaisesti, jotta eri sektorit tukevat toisiaan ja uhrilla on todellinen pääsy oikeuksiinsa.

Istanbulin sopimusta ratifioitaessa nostettiin esiin mahdollinen tarve lainsäädäntömme riittävyyden uudelleenarviointiin. Nyt vuosia myöhemmin tämä arviointi on käynnissä oikeusministeriössä. Ihmisoikeusliitto toimitti 5.4.2018 pakkoavioliittojen kriminalisointia vaativan vetoomuksen oikeusministeri Antti Häkkäselle, joka kertoi oikeusministeriön selvittävän parhaillaan lainsäädännön mahdollisia muutostarpeita. ${ }^{100}$ Oman selvitykseni perusteella väittäisin tämän muutostarpeen olevan olemassa. Sääntely ei ole nykyisellään riittävää, jotta ilmiöön puuttuminen olisi tehokasta. Ongelmistaan huolimatta katson edellä esitettyjen seikkojen puoltavan erilliskriminalisointia.

\section{LÄHTEET}

\section{Lainvalmisteluaineisto}

HE 155/2014 vp - Hallituksen esitys eduskunnalle naisiin kohdistuvan väkivallan ja perheväkivallan ehkäisemisestä ja torjumisesta tehdyn Euroopan neuvoston yleissopimuksen hyväksymisestä sekä laeiksi yleissopimuksen lainsäädännön alaan kuuluvien määräysten voimaansaattamisesta, rikoslain 1 luvun 11 §:n muuttamisesta ja ulkomaalaislain 54 §:n muuttamisesta.

HE 103/2014 vp - Hallituksen esitys eduskunnalle laiksi rikoslain muuttamisesta ja eräiksi siihen liittyviksi laeiksi.

HE 34/2004 vp - Hallituksen esitys Eduskunnalle laiksi rikoslain muuttamisesta

ja eräiksi siihen liittyviksi laeiksi.

HE 309/1993 vp - Hallituksen esitys Eduskunnalle perustuslakien perusoikeussäännösten muuttamisesta.

HE 94/1993 vp - Hallituksen esitys Eduskunnalle rikoslainsäädännön kokonaisuudistuksen toisen vaiheen käsittäviksi rikoslain ja eräiden muiden lakien muutoksiksi.

TyVM 15/2014 vp - Työelämä- ja tasa-arvovaliokunnan mietintö 15/2014 vp. Helsinki 17.2.2015.

Naisiin kohdistuvan väkivallan ja perheväkivallan ehkäisemisestä ja torjumisesta tehdyn

Euroopan neuvoston yleissopimuksen voimaansaattamista valmistelleen työryhmän mietintö. Ulkoministeriö. Helsinki 28.3.2013.

Oikeusministeriön julkaisu 63/2012: Ihmiskauppatyöryhmän mietintö. Helsinki 28.9.2012.

\section{Oikeuskäytäntö}

KHO 2005:87

\section{Muu virallisaineisto}

Explanatory Report CETS 210. Explanatory Report to the Council of Europe Convention on preventing and combating violence against women and domestic violence. Council of Europe Treaty Series - No. 210. Istanbul 2011.

Forced Marriage Unit Statistics 2016. Home Office 9.3.2017.

Global estimates of modern slavery: forced labour and forced marriage. International Labour Organization and Walk Free Foundation. Geneva 2017.

Parliamentary Assembly Resolution 1468 (2005). Forced marriages and child marriages. Council of Europe. 5.10.2005

\section{Toivonen 2017, s. 17 \\ 99 Ensi- ja turvakotien liitto 23.11.2017.}

100 Ihmisoikeusliitto ry 5.4.2018. 


\section{Tutkimuskirjallisuus}

Allain, Jean: Slavery in International Law: Of Human Exploitation and Trafficking. Leiden, Martinus Nijhoff Publishers 2013. (Allain 2013)

Eriksson, Maja Kirilova: The Right to Marry and to Found a Family: A World-Wide Human Right. Uppsala, Almqvist \& Wiksell Internat. 1990. (Eriksson 1990)

Frände, Dan: Yleinen rikosoikeus. Suomentanut Markus Wahlberg. Helsinki, Edita 2005. (Frände 2005)

Hansen, Saana - Sams, Anni - Jäppinen, Maija - Latvala, Johanna: Kunniakäsitykset ja väkivalta - selvitys kunniaan liittyvästä väkivallasta ja siihen puuttumisesta Suomessa. Helsinki, Ihmisoikeusliitto 2016. (Hansen ym. 2016)

Helin, Markku: Suomen kansainvälinen perhe- ja perintöoikeus. Helsinki, Talentum 2013. (Helin 2013)

Hong, Tuuli: Yhteisö, kontrolli ja oikeuden konteksti - suojaako rikoslaki yhteisöllisen väkivallan uhria? Lakimies 3-4/2017, s. 362-386. (Hong 2017)

Jokela, Antti: Rikosprosessi. Helsinki, Talentum 2008. (Jokela 2008)

Korhonen, Kaija - Ellonen, Noora: Maahanmuuttajanaiset väkivallan uhrina. Poliisiammattikorkeakoulun tiedotteita 60/2007. Helsinki 2007. (Korhonen \& Ellonen 2007)

Kyllönen-Saarnio, Eija - Nurmi, Reet: Maahanmuuttajanaiset ja väkivalta: Opas sosiaali- ja terveysalan auttamistyöhön. Sosiaali- ja terveysministeriön oppaita 2005:15. Helsinki 2005. (Kyllönen-Saarnio \& Nurmi 2005)

Lappi-Seppälä, Tapio: 4. Rangaistus kriminaalipolitiikan keinona. Teoksessa Lappi-Seppälä, Tapio - Hakamies, Kaarlo - Koskinen, Pekka - Majanen, Martti - Melander, Sakari - Nuotio, Kimmo - Nuutila, Ari-Matti - Ojala, Timo - Rautio, llkka: Rikosoikeus. Alma Talent Oy, Helsinki 2008. Verkkojulkaisu, saatavissa Alma Talent Fokus -palvelussa, tarkistettu 16.1.2019. (Lappi-Seppälä 2008)

Martikainen, Tuomas - Tiilikainen, Marja: Maahanmuuttajanaiset: käsitteet, tutkimus ja haasteet. Teoksessa Maahanmuuttajanaiset: kotoutuminen, perhe ja työ. Väestöntutkimuslaitoksen julkaisusarja, D 46/2007. Helsinki 2007. (Martikainen \& Tiilikainen 2007)

Mikkola, Tuulikki: Ulkomaisten avioliittojen tunnustaminen Suomessa: kansainvälisen yksityisoikeuden ja oikeusvertailun näkökulmia. Lakimies 5/2013 s. 844-861. (Mikkola 2013)

Melander, Sakari: Rikosoikeudellinen laillisuusperiaate ja rikosoikeudellinen tulkinta. Defensor Legis N:o 4/2015 s. 644-661. (Melander 2015)

Nieminen, Liisa: Perus- ja ihmisoikeudet ja perhe. Helsinki, Talentum 2013. (Nieminen 2013)
Nousiainen, Kevät - Pentikäinen, Merja: Väkivallan vastaisen sopimuksen kivinen ratifiointi Suomessa. Oikeus 4/2013, s. 455-462. (Nousiainen \& Pentikäinen 2013)

Oksanen, Pia Puu: Naisiin kohdistuva väkivalta ihmisoikeuskysymyksenä: tekojen aika? Oikeus 4/2012, s. 618-623. (Oksanen 2012)

Roth, Venla: Defining human trafficking and identifying its victims: a study on the impact and future challenges of international, European and Finnish legal responses to prostitution-related trafficking in human beings. Boston, Martinus Nijhoff Publishers 2012. (Roth 2012)

Rude-Antoine, Edwige: Forced marriages in Council of Europe member states: A comparative study of legislation and political initiatives. Directorate General of Human Rights. Strasbourg, Council of Europe 2005. (Rude-Antoine 2005)

Suomenaro, Eeva: Pakkoavioliitot. Teoksessa Tanja Tauro \& Marjo van Dijken (toim.): Kunnia konfliktina: Näkökulmia ilmiön tunnistamiseen ja ennaltaehkäisyyn. Amoralhankkeen loppujulkaisu. Helsinki, Mannerheimin Lastensuojeluliiton Uudenmaan piiri 2009. (Suomenaro 2009)

Tapani, Jussi - Tolvanen, Matti: Rikosoikeuden yleinen osa: Vastuuoppi. Helsinki, Talentum 2013. (Tapani \& Tolvanen 2013)

Toivonen, Virve: Pakkoavioliittojen esiintyminen ja ilmitulo Suomessa. Selvitysmuistio. Helsinki, Kriminologian ja oikeuspolitiikan instituutti 2017. (Toivonen 2017) 


\section{Internet-lähteet}

Ensi-ja turvakotien liitto: Tiedote: Neljä uutta turvakotia avataan kipeään tarpeeseen. 23.11.2017.

[https://ensijaturvakotienliitto.fi/nelja-uutta-turvakotia-avataan-kipeaan-tarpeeseen/] (vierailtu 2.4.2018)

Helander, Reetta: "Jos et suostu avioliittoon, et ole enää meidän tytär"- Irakin Naisten Yhdistys auttaa pakkoavioliitossa eläviä ja sitä pelkääviä. Ihmisoikeusliiton artikkeli. 23.3.2018. [https://ihmisoikeusliitto.fi/irakin-naisten-yhdistys-auttaa-pakkoavioliitossa-elavia/] (vierailtu 6.4.2018).

Ihmisoikeusliitto ry: Lähes 5500 vetoaa pakkoavioliiton kriminalisoimiseksi Suomessa - Ihmisoikeusliitto luovutti vetoomuksen oikeusministerille tänään. 5.4.2018. [https:// inmisoikeusliitto.fi/yli-5000-vetoaa-pakkoavioliiton-kriminalisoimiseksi/] (vierailtu 6.4.2018).

Melander, Sakari: Miksijärjestäytynyttä rasismia ei kriminalisoitaisi? Perustuslakiblogi. 18.9.2016. [https://perustuslakiblogi.wordpress.com/2016/09/18/sakari-melander-miksi-jarjestaytynyttarasismia-ei-kriminalisoitaisi/] (vierailtu 21.4.2018).

Monika-Naiset liitto ry: Lausunto työvaliokunnalle yhteenvedosta Istanbulin sopimuksen toimeenpano-ohjelmaan esitetyistä toimenpiteistä. 26.10.2017. [https://monikanaiset.fi/ lausunnot/lausunto-tyovaliokunnalle-yhteenvedosta-istanbulin-sopimuksen-toimeenpanoohjelmaan-esitetyista-toimenpiteista/] (vierailtu 29.3.2018).

Monika-Naiset liitto ry: Tiedote: Euroopan neuvoston valtuuskunta kiirehtii pakkoavioliittojen kriminalisointia. 17.6.2016. [https://monikanaiset.fi/uutiset/tiedote-euroopan-neuvostonvaltuuskunta-kiirehtii-pakkoavioliittojen-kriminalisointia/] (vierailtu 26.3.2018).

Oikeusministeriö: Tiedote: Selvitys: Pakkoavioliitot ovat todellisuutta myös Suomessa, viranomaisten koulutusta ja yhteistyötä vahvistettava. 18.10.2017. [http://oikeusministerio.fi /artikkeli/-/asset_publisher/selvitys-pakkoavioliitot-ovat-todellisuutta-myos-suomessaviranomaisten-koulutusta-ja-yhteistyota-vahvistettava] (vierailtu 4.4.2018).

Ulkoministeriö: Lehdistötiedote 105/2015: Suomi hyväksyi naisiin kohdistuvan väkivallan ehkäisemistä ja torjumista koskevan sopimuksen. 17.4.2015

\section{[http://formin.finland.fi/public/}

default.aspx?contentld=325100\&nodeld $=49150 \&$ contentlan $=1 \&$ culture $=f i-F I$

(vierailtu 26.3.2018). 